\title{
Temporal dynamics of carbon flow through the microbial plankton community in a coastal upwelling system off northern Baja California, Mexico
}

\author{
Lorena Linacre $^{1,2, *}$, Michael R. Landry ${ }^{3}$, Ramón Cajal-Medrano ${ }^{4}$, \\ J. Rubén Lara-Lara ${ }^{5}$, J. Martín Hernández-Ayón ${ }^{6}$, Rosa R. Mouriño-Pérez ${ }^{2}$, \\ Ernesto García-Mendoza ${ }^{5}$, Carmen Bazán-Guzmán ${ }^{5}$
}

${ }^{1}$ Programa de Doctorado en Oceanografía Costera, Facultad de Ciencias Marinas/Instituto de Investigaciones Oceanológicas, ${ }^{4}$ Facultad de Ciencias Marinas, and ${ }^{6}$ Instituto de Investigaciones Oceanológicas; Universidad Autónoma de Baja California (UABC), Ensenada, Baja California 22860, Mexico

${ }^{2}$ Departamento de Microbiología, División de Biología Experimental y Aplicada, and

${ }^{5}$ Departamento de Oceanografía Biológica, División de Oceanología; Centro de Investigación Científica y de Educación Superior de Ensenada (CICESE), Ensenada, Baja California 22860, Mexico

${ }^{3}$ Scripps Institution of Oceanography, University of California at San Diego, La Jolla, California 92093-0227, USA

\begin{abstract}
We investigated the temporal dynamics of carbon flow through the microbial food web of a coastal upwelling system (ENSENADA station) off northern Baja California during 6 cruises (September 2007 to November 2008). Carbon biomass assessments for major autotrophic size groups (pico- to micro-sized cells) and their microzooplankton grazers were based on analyses using flow cytometry, HPLC pigments and epifluorescence microscopy. Taxon-specific phytoplankton growth and microzooplankton grazing rates were determined from $24 \mathrm{~h}$ in situ incubations in the euphotic zone using an abbreviated 3-treatment dilution technique. Carbon biomass and instantaneous growth and grazing rate determinations were used to estimate daily rates of taxon-specific production and losses due to microzooplankton grazing. Overall, microbial biomass showed a close balance between autotrophic and heterotrophic components, except during a period of very strong upwelling (April 2008), which favored large phytoplankters and high primary production. Throughout a wide range of environmental conditions, the community primary production (PP) attributed both to small (mostly picophytoplankton and prasinophytes) and large (mostly diatoms and autotrophic dinoflagellates) autotrophs was significantly grazed ( $78 \pm 9 \%$ of PP) by small $(<20 \mu \mathrm{m})$ and large $(>20 \mu \mathrm{m})$ ciliates and flagellates (including mixotrophic dinoflagellates), respectively, showing complementary temporal shifts in protistan grazer types that matched the dominant phytoplankton. While large diatoms were strongly consumed by large ciliates during the 2 most productive periods (September 2007 and April 2008), pico- and nano-sized phytoplankton were grazed most by nanoflagellates and small ciliates from November 2007 to January 2008. Consequently, biogenic carbon production in this ecosystem is transferred through a multivorous food web.
\end{abstract}

KEY WORDS: Biogenic carbon flow - Multivorous food web - Phytoplankton growth rate · Phytoplankton grazing rate $\cdot$ Primary production

Resale or republication not permitted without written consent of the publisher

\section{INTRODUCTION}

Many productive pelagic environments have multivorous food webs, in which both classic herbivorous food chains (large phytoplankton, suspension-feed- ing zooplankton and fish) and microbial trophic components (heterotrophic bacteria, cyanobacteria, small eukaryotic algae and protozooplankton) contribute significantly to carbon fluxes. Thus, the fate of primary production with regard to carbon cycling 
within the upper layer or export to the deep ocean depends on temporal variability in the relative strengths of these alternate trophic pathways (Legendre \& Rassoulzadegan 1995, 1996).

Within the microbial food web, nano- to microsized grazers $<200 \mu \mathrm{m}$ in size (here defined collectively as the microzooplankton) are ubiquitous and major consumers of small and large primary producers as well as heterotrophic bacteria (Sherr \& Sherr 2002, Calbet 2008). To quantify the general magnitude of the phytoplankton-microzooplankton trophic link, experimental studies of phytoplankton growth and microzooplankton grazing have been conducted in a variety of oceanic habitats using the dilution technique (Landry \& Hassett 1982). On average, microzooplankton consume $\sim 67 \%$ of phytoplankton daily production over a broad range of habitat types (Calbet \& Landry 2004). Most of the remaining net production is believed to be grazed by mesozooplankton. The mean estimate for mesozooplankton grazing loss is $22.6 \%$ of primary production (PP), but it can vary substantially by system trophic state (Calbet 2001). Recent studies that have examined the grazing contributions of both micro- and mesozooplankton in open-ocean and coastal systems have shown that the difference between measured production and the combined losses to the 2 grazer size fractions largely explain the net daily changes in phytoplankton biomass observed in the environment (Landry et al. 2009, 2011).

Because upwelling regions are highly productive and potentially important in transferring carbon from continental shelves to slopes (Walsh et al. 1981), more knowledge of the magnitude and temporal variability of pelagic food web activity in these regions is needed. Under the contrasting environmental conditions that drive the production dynamics of such systems, carbon fluxes are strongly responsive to the dominant size structure and composition of the phytoplankton community (Latasa et al. 2005, Gutiérrez-Rodríguez et al. 2010) and to the balance between the phytoplankton production and its grazing loss due to consumers of different types and sizes. Thus, while coastal upwelling areas are typically viewed as diatom dominated, implying strong linkages to suspension-feeding metazoans and higher level consumers, substantial portions of the system productivity can be channeled through smaller autotrophs and microbial pathways, including direct consumption of diatoms by protists (Neuer \& Cowles 1994, Landry et al. 2000a, 2009, Stelfox-Widdicombe et al. 2004, Aberle et al. 2007, Sherr \& Sherr 2007, Vargas et al. 2007, Teixeira et al. 2011). Rapid re- sponse of the protistan grazer assemblage to large system swings in the biomass and composition of phytoplankton prey promotes a planktonic food web characterized by efficient utilization of primary production and carbon and nutrient cycling within the euphotic zone (Calbet \& Landry 2004).

In the coastal upwelling region off western Baja California (WBC), picoplankton populations (autotrophic and heterotrophic) contribute significantly to carbon fluxes, with temporal dynamics strongly influenced by seasonal oceanographic conditions (Linacre et al. 2010a,b). In the present study, we combine microscopic and flow cytometric (FCM) assessments of community biomass and composition with experimental studies of growth and grazing rates to gain a broader perspective of carbon-based production and grazing for different phytoplankton groups. Our general hypothesis is that a strong coupling exists between phytoplankton carbon production and grazing losses to microzooplankton, which involves complementary shifts in protistan grazer types to match the temporal variability of dominant phytoplankton. In this context, our main goal is to evaluate the contribution of different phytoplankton groups to community biomass, production and grazing under differing environmental conditions. Our results highlight the general multivorous nature of carbon fluxes through the microbial plankton community in this coastal upwelling system.

\section{MATERIALS AND METHODS}

\section{Sampling and experimental design}

Experimental studies of phytoplankton growth and protistan grazing were conducted at ENSENADA station $\left(31^{\circ} 40.105^{\prime} \mathrm{N}, 116^{\circ} 41.596^{\prime} \mathrm{W}\right)$ in the northern region off WBC (Fig. 1) as part of the FLUCAR (Carbon Sources and Sinks in the Continental Margins of the Mexican Pacific Waters) project. During the period from 24 September 2007 to 11 November 2008, 6 sets of experiments were incubated in situ for $24 \mathrm{~h}$ at the station. Following the experimental approach of Landry et al. (2008), we used an abbreviated 3-treatment dilution protocol (100, 30 and 10\% of whole seawater, without an addition of nutrients and non-replicated) to estimate rates of phytoplankton growth and microzooplankton grazing. Based on in situ fluorescence profiles, seawater for the experiments was collected in 51 Niskin bottles from the euphotic zone at the subsurface chlorophyll maximum (SCM) and from the depths above and below 

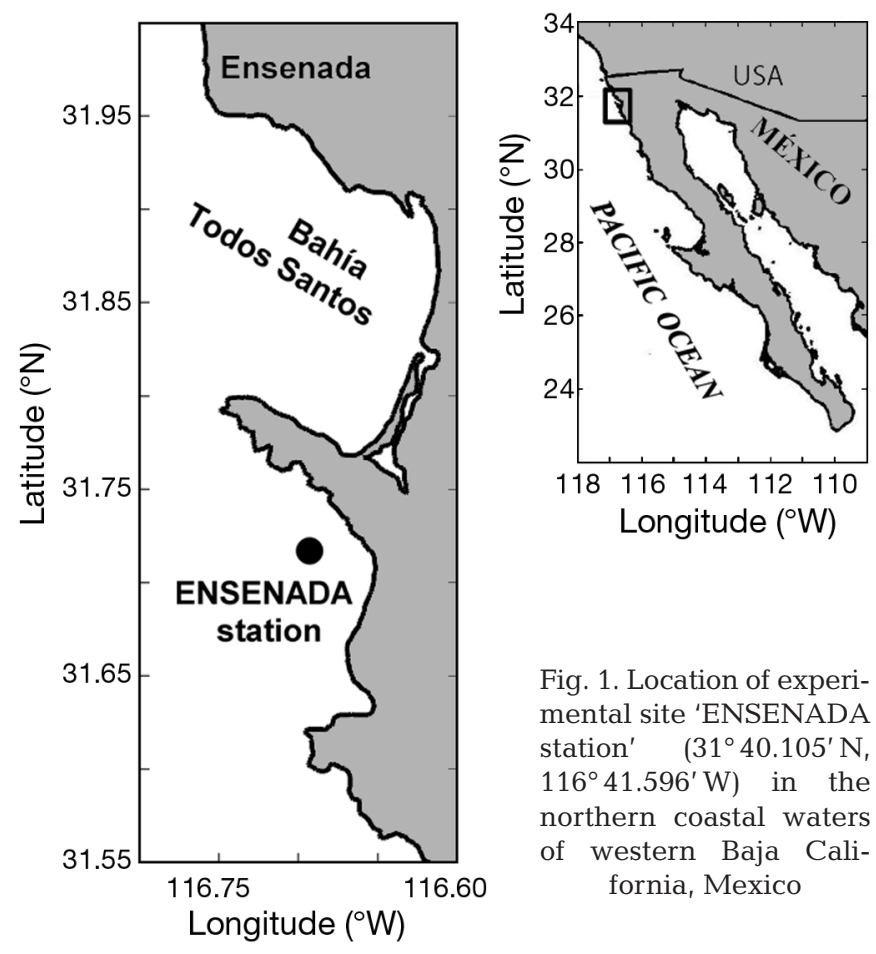

Fig. 1. Location of experimental site 'ENSENADA station' $\left(31^{\circ} 40.105^{\prime} \mathrm{N}\right.$, $116^{\circ} 41.596^{\prime} \mathrm{W}$ ) in the northern coastal waters of western Baja California, Mexico

the SCM. Details of the experimental design are described by Linacre et al. (2010a). Briefly, dilution treatments $(10,30$ and $100 \%$ of natural plankton density) were prepared in clear polycarbonate bottles (2 1), mixing a whole seawater fraction with water directly filtered from the Niskin bottles using a peristaltic pump, silicone tubing and an in-line Suporcap filter capsule. The bottles were tightly capped, placed into net bags, secured with snap hooks to a weighted line hanging from surface floats and attached to a fixed buoy at the depths of initial sample collection. The experiments were conducted in the early morning and deployed prior to sunrise.

\section{Picoplankton analyses}

Samples were taken for FCM analyses at the start and end of each experiment to determine initial abundances and to compute carbon biomass and cellspecific growth and grazing loss rates in the dilution incubations. For enumeration of picophytoplankton and heterotrophic bacteria, $2 \mathrm{ml}$ samples were preserved (in $0.5 \%$ paraformaldehyde, final concentration), flash frozen and stored in liquid nitrogen until analysis. Samples were analyzed with a BeckmanCoulter Altra cytometer following the approach described by Linacre et al. (2010a) and Taylor et al. (2011). The cell abundances of heterotrophic bacteria
(H-Bact), Prochlorococcus spp. (Pro), Synechococcus spp. (Syn) and picoeukaryotes (P-Euks) were converted to carbon biomass based on carbon per cell conversions estimated for each category by cruise and depth using bead-normalized forward-angle light scattering (FALS) to assess cell biovolume (BV) variability. For each cell category, we assumed a mean cell carbon estimate from literature values 20, 39, 82 and $1000 \mathrm{fg} \mathrm{C} \mathrm{cell}^{-1}$ for H-Bact, Pro, Syn and PEuks, respectively (Lee \& Fuhrman 1987, Worden et al. 2004, Sherr et al. 2005). We then used the FALS ratio $\left(\text { FALS }_{\text {sample: }} \text { FALS }_{\text {mean }}\right)^{0.55}$ as a scaling factor for the cell size variability of each population (Linacre et al. 2010a and literature therein). According to these calculations, the ranges in cell carbon estimates were 16 to 24 (H-Bact), 34 to 47 (Pro), 64 to 119 (Syn) and 608 to $1421 \mathrm{fg} \mathrm{C} \mathrm{cell}^{-1}$ (P-Euks). For size structure assessments, we assumed that the largest 'pico' sized cells were $2 \mu \mathrm{m}$ in diameter, although some in the enumerated P-Euks category may have been larger than this formal cut-off (Linacre et al. 2010a).

\section{Pigment analyses}

Seawater samples (1 l) were collected for pigment analysis at the start and end of each experiment. Samples were filtered through $25 \mathrm{~mm}$ diameter glass fiber filters (GF/F) and frozen immediately in liquid nitrogen until analysis. Pigment extraction was conducted following the procedures described by Almazán-Becerril \& García-Mendoza (2008). Filters were placed in $2 \mathrm{ml}$ capped tubes with $0.5 \mathrm{~mm}$ diameter zirconia/glass beads in $1 \mathrm{ml}$ of cold acetone $(100 \%)$, vortexed and stored at $4^{\circ} \mathrm{C}$ in a process repeated 3 times. The samples were cleaned by centrifugation. Pigments were quantified using high performance liquid chromatography (HPLC) as in Van Heukelem \& Thomas (2001), as modified by Colombo-Pallotta et al. (2006). The samples were analyzed in a Shimadzu AV-10 series HPLC instrument equipped with a Zorbax Eclipse XDBC-8 reverse phase column $(150 \mathrm{~mm} \times 4.6 \mathrm{~mm}$ internal diameter, $3.5 \mu \mathrm{m}$ particles, $60^{\circ} \mathrm{C}$ ). An absorption detector was set up at $436 \mathrm{~nm}$. Pigment peaks in the chromatograms were identified by comparison of the retention times with those of pure standards and extracts prepared from algal cultures of known pigment composition. This protocol achieves baseline separation of monovinyl chlorophyll a (MVChl a) and divinyl chlorophyll a (DVChl a) and was calibrated with 16 pigment standards (DHI; www.labproducts. dhigroup.com). Standard purity determination and 
the calibration protocol were as in Wright \& Mantoura (1997).

Taxonomic assignments for the major pigments measured were based on known pigment compositions (Jeffrey \& Vesk 1997, Wright \& Jeffrey 2006). Significant peaks of chlorophyllide $a$ (Chlide $a$ ), were seen in the chromatograms during the September 2007 and April 2008 cruises, possibly due to filtration damage of the abundant large diatom chains during those seasons (Wright \& Mantoura 1997). Therefore, total chlorophyll a (TChl a), a proxy for the total autotrophic community, was composed of MVChl a + DVChl $a+$ Chlide $a$ (for the September 2007 and April 2007 cases), following the approach of Latasa \& Bidigare (1998). MVChl $a$ is found in all eukaryotic phytoplankton and in the photosynthetic prokaryote Synechococcus spp. DVChl a, only weakly detected in our HPLC analyses, is a specific marker for Prochlorococcus. The pigments 19'-hexanoyloxyfucoxanthin (Hex-Fuco) and 19'-butanoyloxyfucoxanthin (But-Fuco) are found in both prymnesiophytes and pelagophytes, but Hex-Fuco occurs in higher concentrations in prymnesiophytes, while But-Fuco (more weakly detected in our samples) is the dominant accessory pigment of pelagophytes. Fucoxanthin (Fuco) was assumed in the present study to be mostly indicative of diatoms, although it can also be found in prymnesiophytes and pelagophytes. Prasinoxanthin (Prasinox) is found in some types of prasinophytes, and alloxanthin (Allox) is an unambiguous marker for cryptophytes. Both pigments were detected at moderate levels in our samples. Peridinin (Perid) is found only in dinoflagellates, although it is absent or very low in many taxa. This biomarker was occasionally detected in the present study, but it contributed minimally to the total phytoplankton community pigments (Jeffrey \& Vesk 1997, Wright \& Jeffrey 2006).

\section{Microscopic assessments of nano- and microplankton}

Estimates of carbon biomass for size classes and functional groups of autotrophic and heterotrophic eukaryotes (grazers) were made by digitally enhanced epifluorescence microscopy on 2 slide preparations, after freezing and storage at $-30^{\circ} \mathrm{C}$, using the methodology described by Taylor et al. (2011). Cells $<10 \mu \mathrm{m}$ in size were enumerated in seawater samples of $50 \mathrm{ml}$, preserved with paraformaldehyde $(0.5 \%$ final concentration), stained with proflavin $(0.33 \%$ $\mathrm{w} / \mathrm{v})$ and DAPI $\left(10 \mu \mathrm{g} \mathrm{m} \mathrm{m}^{-1}\right)$ and mounted onto
$0.8 \mathrm{~mm}$ black Nuclepore filters. Larger cells were enumerated from $500 \mathrm{ml}$ samples, preserved with $260 \mu \mathrm{l}$ of alkaline Lugol's solution followed by $10 \mathrm{ml}$ of buffered formalin and $500 \mu \mathrm{l}$ of sodium thiosulfate (modified protocol from Sherr \& Sherr 1993), stained with proflavin $(0.33 \% \mathrm{w} / \mathrm{v})$ and DAPI $\left(10 \mu \mathrm{g} \mathrm{ml}^{-1}\right)$ and mounted onto $8 \mu \mathrm{m}$ black Nuclepore filters. The slides were imaged and digitized at $630 \times(50 \mathrm{ml})$ and $200 \times(500 \mathrm{ml})$ using a Zeiss AxioVert 200M inverted epifluorescence microscope with an AxioCam HR black/white digital camera. Cell BV $\left(\mu \mathrm{m}^{3}\right)$ were determined from length $(L)$ and width $(W)$ measurements using the formula for a prolate sphere $(\mathrm{BV}=$ $0.524 \times L \times W \times H)$, where cell height $(H)$ on the filters was empirically determined to be $0.5 \mathrm{~W}$ for naked flagellates (including dinoflagellates) (Taylor et al. 2011). Carbon $\left(C_{i}\right.$ pg cell $\left.{ }^{-1}\right)$ biomass was computed from BV from the equations of Menden-Deuer \& Lessard (2000): $\mathrm{C}=0.216 \times \mathrm{BV}^{0.939}$ for non-diatoms, and $\mathrm{C}=0.288 \times \mathrm{BV}^{0.811}$ for diatoms.

For each experiment, $250 \mathrm{ml}$ samples were also fixed with $5 \%$ acid Lugol's solution for a biomass estimation of ciliates (Cil), which were sub-optimally preserved by the other methods and rarely counted on the slides. Subsamples of $10 \mathrm{ml}$ (for September 2007 and April 2008) and $50 \mathrm{ml}$ (for November 2007/08, January 2008 and August 2008) were settled in Utermöhl sedimentation chambers for at least $24 \mathrm{~h}$, counted, sorted by size class to $>20$ and $<20 \mu \mathrm{m}$ and measured at $400 \times$ with a Zeiss AxioVert 200 inverted microscope equipped with an AxioCam HRc color digital camera (Microbiology Department, CICESE). BV $\left(\mu \mathrm{m}^{3}\right)$ estimates were based on measured $L$ and $W$ dimensions and the closest geometric shapes for individual cells (50 to 100 cells) collected from the SCM. To convert cell BV estimates to carbon, we used the equations $\mathrm{C}(\mu \mathrm{g})=0.12+0.19 \mathrm{BV}$ $\left(\mu \mathrm{m}^{3}\right)$ for naked ciliates (Putt \& Stoecker 1989) and C

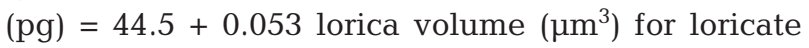
ciliates (Verity \& Langdon 1984). Median cell carbon estimates for each of the $>20$ and $<20 \mu \mathrm{m}$ ciliate size classes were used to calculate ciliate carbon biomass for each cruise and depth sample.

Microzooplankton grazers in this coastal system were mainly represented by $\mathrm{Cil}$ and heterotrophic and mixotrophic flagellates (dinoflagellates included; H-Flag and H-Dino). To represent the potential grazing contribution of mixotrophic groups, we followed the approach of Landry et al. (2011), based on the empirical results of Stukel et al. (2011), and counted half of the biomass of autotrophic flagellates (A-Flag, including dinoflagellates) as contributors to grazing on phytoplankton. 


\section{Growth and grazing estimates}

Instantaneous rates of phytoplankton growth $(\mu)$ and mortality loss $(m)$ due to protistan grazers were estimated from dilution incubations in accordance with Landry \& Hassett (1982), using the abbreviated 3 -treatment dilution protocol described by Linacre et al. (2010a). Initial pigment concentrations and population abundances $\left(C_{0}\right)$ from HPLC and FCM analyses, respectively, were determined for each dilution treatment from measured concentrations in the unfiltered seawater $(100 \%)$ and the proportion of unfiltered $\left(D_{i}\right)$ seawater in the treatment $i$. Final concentrations $\left(C_{t}\right)$ were measured in each bottle at the end of the $24 \mathrm{~h}$ incubations $(t)$. Daily net-specific rates of change were estimated as $k_{i}=\ln \left(C_{t} / C_{0}\right) / t$, where $C_{0}$ and $C_{t}$ are expressed as $\mu \mathrm{g} \mathrm{Cl^{-1 }}$. For picophytoplankton populations (Pro, Syn and P-Euks), $k_{i}$ was computed from FCM cell abundances in each dilution treatment. For total autotrophs (Total Phyto), diatoms, prymnesiophytes (Prym), prasinophytes (Pras), and cryptophytes (Cryp), we used changes in TChl $a_{\text {, }}$ Fuco, Hex-Fuco, Prasinox and Allox concentrations, respectively. The signals from minor pigments, such as But-Fuco, DVChl a and Perid, were generally too weak and occasional for rate calculations. The typical linear relationship between $k_{i}$ and $D_{i}$ allowed estimation of $m$ and $\mu$ daily rates from the slopes and intercepts of the trendlines, respectively. However, deviations of linearity were seen on a few occasions (mainly for the pigment data), and the $\mu$ and $m$ rates for these experiments were estimated from 2 dilution treatments (100 and $30 \%$ ) following the 2-treatment dilution approach of Landry et al. $(2008,2009)$. Saturated grazing was also seen when a $k_{i}$ estimate for the undiluted treatment exceeded the estimates for the 30 and $10 \%$ treatments, as described by Teixeira \& Figueiras (2009). For this case, $\mu$ was calculated from the 10 and $30 \%$ treatments, and $m$ was determined as the difference between $\mu$ and the net growth rate in the undiluted treatment (Teixeira \& Figueiras 2009). Lastly, for 2 incubations, a positive relationship was found between $D_{i}$ and $k_{i}$. For these, we used the measured rates of change in the undiluted bottles, which involved no experimental manipulation, as a minimum estimate of $\mu$ (Landry et al. 2008).

Additionally, we corrected the pigment-based growth rate estimates for photoacclimation effects during the incubations with a method adapted from Landry et al. (2003) and Gutiérrez-Rodríguez et al. (2010). Using PEuks as a proxy for the eukaryotic phytoplankton community, we computed the ratios of P-Euks red fluorescence $\left(F_{1}\right)$ to forward scatter $\left(F_{S}\right)$ per cell from
FCM analyses (an estimate of chl a:C ratio) to reflect the proportion of pigment change that was not due to growth of phytoplankton carbon biomass. We used the change in the $F_{1} / F_{S}$ ratio from initial and final whole seawater measurements to compute daily instantaneous rates of change for the $24 \mathrm{~h}(t)$ incubations as $\ln \left[\left(\mathrm{F}_{1} / \mathrm{F}_{\mathrm{S}}\right)_{\mathrm{f}} /\left(\mathrm{F}_{1} / \mathrm{F}_{\mathrm{S}}\right)_{i}\right] / t$. These pigment acclimation corrections were applied by subtracting them from $\mu$ estimates based on measured TChl $a$ changes for the total autotrophic community or from $\mu$ based on pigment-specific changes in diatoms $(\mu$ Fuco), prymnesiophytes ( $\mu$ Hex-Fuco), prasinophytes ( $\mu$ Prasinox) and cryptophytes ( $\mu$ Allox).

\section{Primary production and grazing loss estimates}

Experimental values of $\mu$ and $m$ were combined with carbon biomass estimates $\left(C_{0}\right)$ in accordance with Landry et al. (2000a) to compute carbon-based estimates of production and grazing rates for the total autotrophic community (TChl a based) and its component populations (taxon-specific cell and pigment based). Daily PP estimates and biomass consumption by protistan grazers $(G)$ expressed in carbon $\left(\mu \mathrm{C} \mathrm{Cl}^{-1}\right.$ $\mathrm{d}^{-1}$ ) are computed as follows:

$$
\begin{aligned}
& \mathrm{PP}=\mu\left(C_{0}\left[\mathrm{e}^{(\mu-m) t}-1\right] /([\mu-m] \times t)\right. \\
& G=m\left(C_{0}\left[\mathrm{e}^{(\mu-m) t}-1\right] /([\mu-m] \times t)\right.
\end{aligned}
$$

PP and $G$ for diatoms, prymnesiophytes, prasinophytes, cryptophytes, picoeukaryotes, Synechoccoccus and Prochlorococcus were estimated from their C-based standing stocks $\left(C_{0}\right)$ and specific-rates $(\mu$ and $m$ ) based on Fuco, Hex-Fuco, Prasinox, Allox pigments, as well as P-Euks, Syn and Pro cell abundances, respectively. Based on strong correlation between chlorophyll $b$ and prasinoxanthin concentrations $\left(\mathrm{R}^{2}=0.90, \mathrm{p}<0.0001\right)$ and low ratios of lutein to chlorophyll $b$ (Lut:chl $b=0-0.04$; Wright \& Jeffrey 2006), we assumed that prasinophytes dominated the small green algae group. Thus, A-Flag carbon biomass, attributed mostly to prasinophytes, was used to estimate the dynamics of this algal taxon. Production and grazing loss rates for other nano/ micro-sized autotrophic eukaryotes (Other A-Euks) that could not be attributed to a specific phytoplankton group (mostly autotrophic dinoflagellates, A-Dino) were computed from rate estimates based on chl $a$ ( $\mathrm{chl} a=$ MVChl $a+$ Chlide $a$ ) and total biomass for all chl $a$ containing autotrophs (= total biomass - Pro). After the total production of the chl a-containing assemblage was determined, the production rates for diatoms, prymnesiophytes, prasinophytes, cryptophytes, 
P-Euks and Syn were subtracted to yield the contribution of Other A-Euks (Landry et al. 2011). The ratios of grazing losses to production rates $(G: P P=$ $m: \mu)$ were estimated as measures of the daily protistan grazing impact on the production of the phytoplankton community (TChl a based) and on taxonspecific phytoplankton groups (based on FCM and pigment-specific rates). For averaging, the G:PP ratios for each cruise and depth level were arctangent transformed as in Calbet \& Landry (2004).

As a basis of comparison to population production estimates from dilution experiments, we also measured primary productivity using the standard ${ }^{14} \mathrm{C}$-bicarbonate-uptake technique (Steemann-Nielsen 1952). Briefly, after screening through a $150 \mu \mathrm{m}$ net to exclude mesozooplankton, we inoculated the seawater samples with $\sim 5 \mu \mathrm{Ci} \mathrm{NaH}{ }^{14} \mathrm{CO}_{3}$ in $250 \mathrm{ml}$ polycarbonate bottles. Replicated light and dark bottles were placed into net bags simultaneously with dilution bottles and incubated in situ for $24 \mathrm{~h}$. Primary production rates were calculated based on radioactivity measurements with a Beckman LS-6500 scintillation counter, in accordance with Parsons et al. (1984).

\section{RESULTS}

\section{Autotrophic and heterotrophic carbon biomasses}

The TChl $a$, total autotrophic (Auto-C) and heterotrophic (Hetero-C) carbon biomasses $<200 \mu \mathrm{m}$ as well as relative contributions of size classes and specific groups are shown in Figs. 2, $3 \& 4$. The total plankton carbon biomass was highest $\left(>150 \mu \mathrm{g} \mathrm{C} \mathrm{l}^{-1}\right)$ in September 2007 and April 2008 and lowest $\left(<50 \mu \mathrm{g} \mathrm{C} \mathrm{l}^{-1}\right)$ during the November cruises. For all samples, Auto-C was $58 \%$ of the total carbon biomass, and Hetero-C composed $42 \%$, of which $>70 \%$ was prokaryotes (Figs. 2a \& 4b).

Similar trends were seen for Auto-C and TChl a during the study period. Auto-C and TChl a values were highly variable in the euphotic zone, ranging

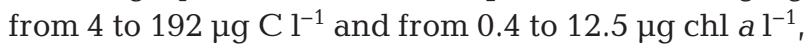
respectively. Extraordinary bloom levels of Auto-C and TChl a were found in April 2008 (Fig. 2a). The C:TChl a ratios for the phytoplankton community averaged ( $\pm 1 \mathrm{SE}) 24.9 \pm 2.5$ (Fig. $2 b$ ).

Pico- and nanoplankton were the major contributors to the total Auto-C and Hetero- $\mathrm{C}$ for all cruises and depths, except during April 2008, when total carbon was mostly due to nano- and micro-sized cells (Fig. 3). The autotrophic picoplankton (A-Pico) biomass ranged

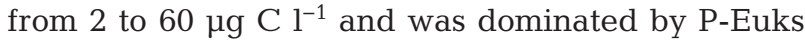
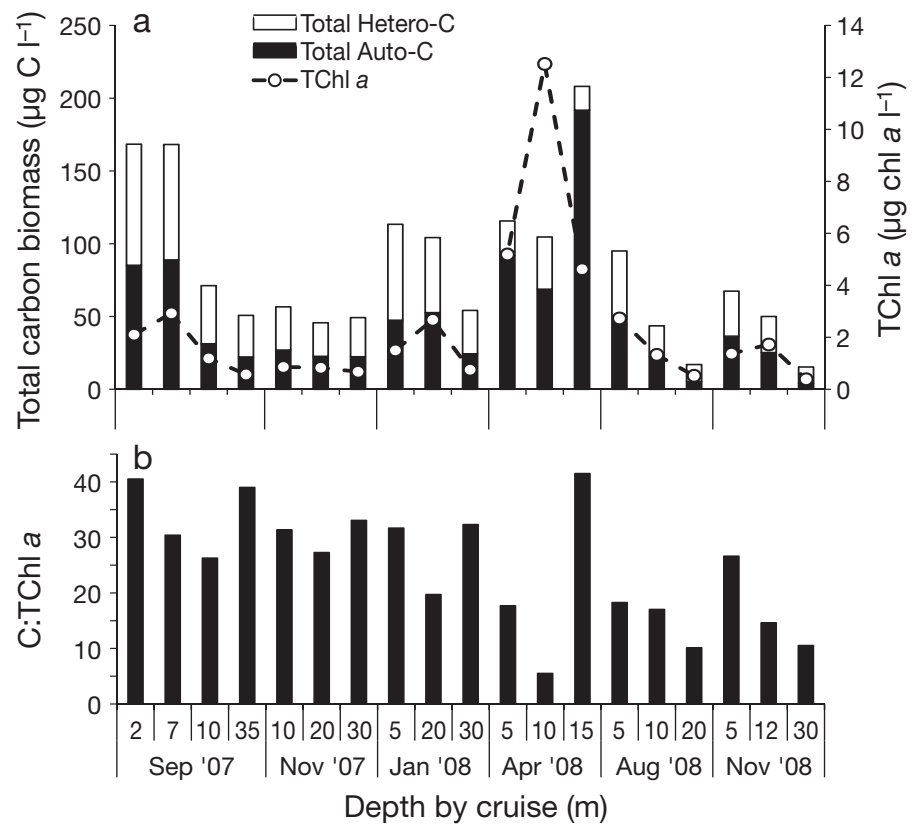

Fig. 2. (a) Total autotrophic (Auto-C) and heterotrophic (Hetero-C) carbon biomass (left $y$-axis) and total concentration of chlorophyll a (TChl $a$; right $y$-axis) and (b) Auto-C to $\mathrm{TChl}$ a ratios, from initial conditions of dilution experiments conducted from September 2007 to November 2008 at ENSENADA station

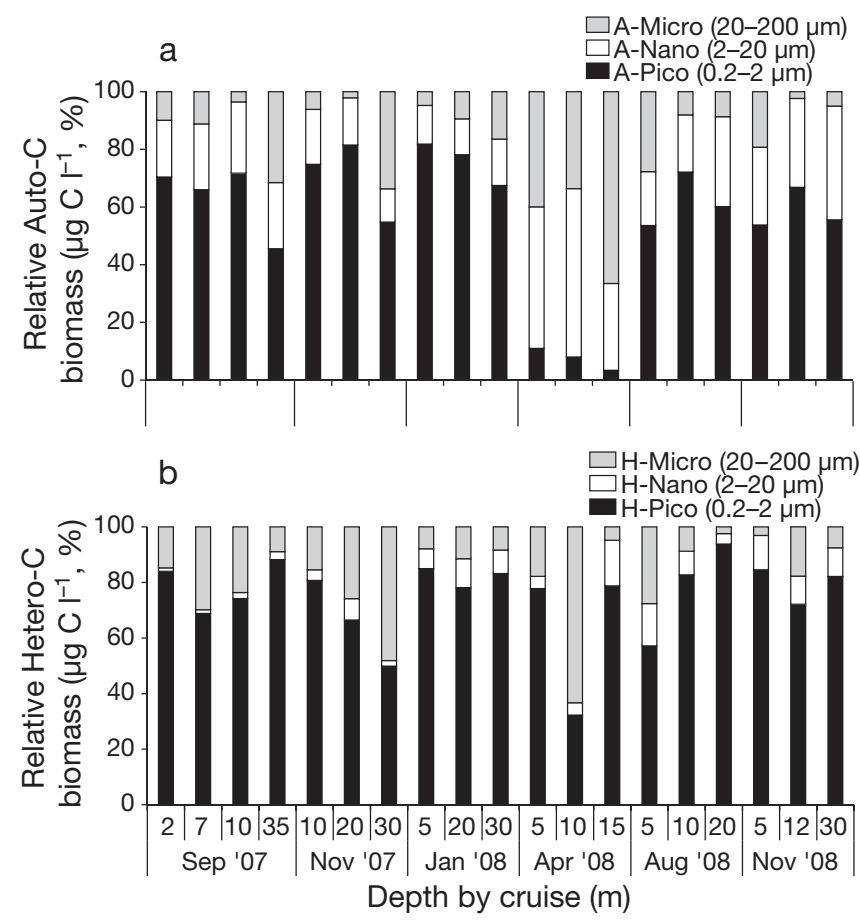

Fig. 3. Relative contribution to total carbon biomass $<200 \mu \mathrm{m}$ of (a) autotrophic carbon (Auto-C) and (b) heterotrophic carbon (Hetero-C) by phytoplankton size class from initial conditions of dilution experiments from September 2007 to November 2008 at ENSENADA station. Note that heterotrophic pico-sized cells (H-Pico) consist entirely of heterotrophic bacteria 

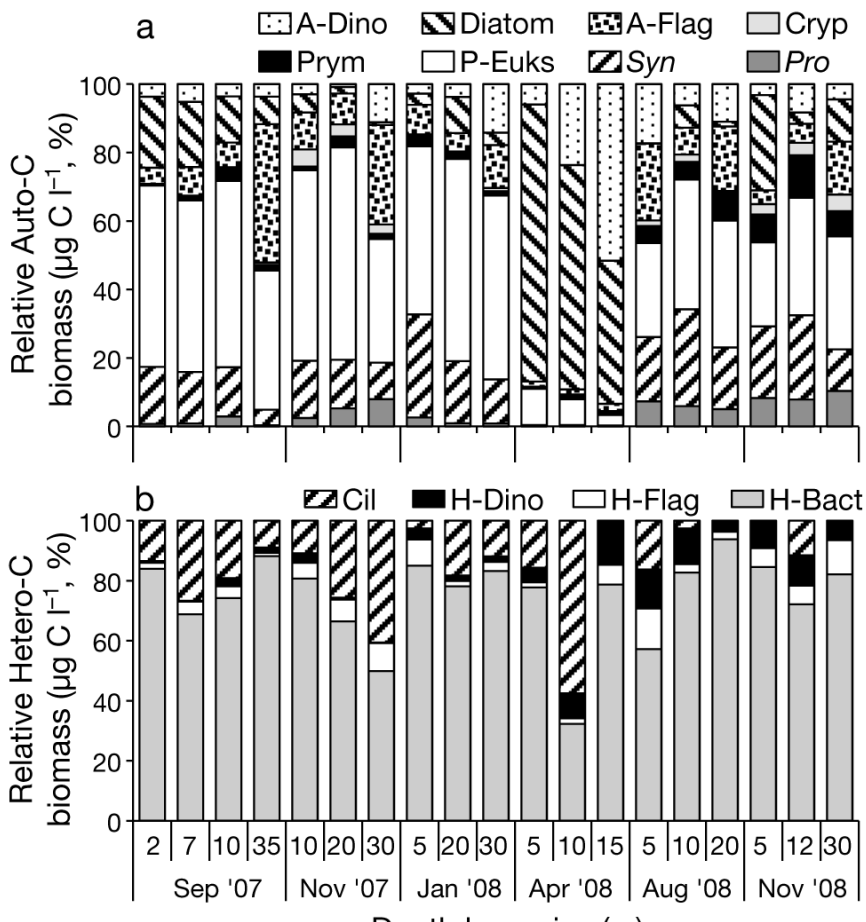

Depth by cruise $(\mathrm{m})$

Fig. 4. Relative contribution to total carbon biomass $<200 \mu \mathrm{m}$ of (a) autotrophic carbon (Auto-C) and (b) heterotrophic carbon (Hetero-C) according to group from initial conditions of dilution experiments from September 2007 to November 2008 at ENSENADA station. A-/H-: auto/heterotrophic: Dino: dinoflagellates; Flag: flagellates; Cryp: cryptophytes; Prym: prymnesiophytes; P-Euks: pico-eukaryotes; Syn: Synechococcus spp.; Pro: Prochlorococcus spp.; Cil: ciliates; Bact: bacteria

and Syn (Fig. 4a). Heterotrophic picoplankton (HPico), composed entirely of H-Bact, ranged from 9 to $70 \mu \mathrm{g} \mathrm{Cl}^{-1}$ (Fig. 4b). The autotrophic nanoplankton (A-Nano) biomass, represented mainly by autotrophic nanoflagellates (A-Flag) and $<20 \mu \mathrm{m}$ chain-forming diatoms, especially during September 2007 and April 2008, varied from 2 to $58 \mathrm{\mu g} \mathrm{Cl}^{-1}$ (Fig. 4a). The heterotrophic nanoplankton (H-Nano) biomass, principally composed of heterotrophic nanoflagellates (H-Flag) and some small $(<20 \mu \mathrm{m})$ heterotrophic dinoflagellates (H-Dino), varied from 0.4 to $7 \mu \mathrm{C} \mathrm{Cl}^{-1}$ (Fig. $4 \mathrm{~b}$ ). For micro-sized cells (autotrophic: A-Micro; heterotrophic: H-Micro), Auto-C (0.2 to $128 \mu \mathrm{g} \mathrm{Cl}^{-1}$ ) was dominated by diatoms and dinoflagellates (Fig. 4a), whereas Hetero-C ( 0.3 to $24 \mathrm{\mu g} \mathrm{C} \mathrm{l}^{-1}$ ) was represented mainly by ciliates and H-Dino (Fig. 4b).

\section{Experimental rate estimates}

Estimates of $\mu$ and $m$ were computed for the autotrophic community ( $\mathrm{TChl}$ a) and for major phytoplankton groups based on the measured net changes in TChl a and taxon-specific pigments or FCM cell abundances, respectively (Table 1). Instantaneous growth and grazing rates $>0$ for the whole phytoplankton community ranged from 0.24 to $1.62 \mathrm{~d}^{-1}$ and from 0.34 to $2.64 \mathrm{~d}^{-1}$, respectively. Mean $( \pm 1 \mathrm{SE})$ values for $\mu$ and $m$ were $0.9 \pm 0.1 \mathrm{~d}^{-1}$ and $0.7 \pm 0.1 \mathrm{~d}^{-1}$, respectively. Mean growth rates modestly exceeded grazing losses for most phytoplankton groups, but the rate differences were more pronounced for larger taxa, like diatoms (Table 1).

Estimates of carbon biomass production (PP) and $G$ based on TChl $a \mu$ and $m$ rates for the phytoplankton community showed marked seasonal variability (Fig. 5a). Daily PP rates $>0$ ranged from 4 to $276 \mu \mathrm{g} \mathrm{C} \mathrm{l}^{-1} \mathrm{~d}^{-1}$, and $G$ varied from 3 to $155 \mu \mathrm{g} \mathrm{C}^{-1}$ $\mathrm{d}^{-1}$. Mean $( \pm 1 \mathrm{SE})$ values of PP and G were $55 \pm 16 \mu \mathrm{g}$ $\mathrm{Cl}^{-1} \mathrm{~d}^{-1}$ and $36 \pm 9 \mu \mathrm{g} \mathrm{Cl}^{-1} \mathrm{~d}^{-1}$, respectively. Taxonspecific estimates of PP and $G$ calculated for phytoplankton groups showed variable contributions to seasonal carbon fluxes during the study period (Fig. 5b,c). Highest total production and grazing losses were measured in the upper mixed layer during September 2007 and April 2008 (Fig. 5a), mainly associated with larger autotrophic cells (diatoms and Other A-Euks). P-Euks also contributed notably to production and grazing rates in September 2007 (Fig. 5b,c). Low PP and $G$ measurements were made during cold conditions (November 2007/08 and January 2008), mostly associated with smaller algal cells. Net production (= PP $-G$ ) was generally positive in the experimental incubations, except for a few cases in September 2007, January 2008 and April 2008 (Fig. 5a). Additionally, production estimates from the dilution experiments (TChl a based) were similar to net rates of ${ }^{14} \mathrm{C}$-uptake (Fig. 5a), which ranged from 0.24 to $217 \mu \mathrm{g} \mathrm{Cl}^{-1} \mathrm{~d}^{-1}$, with a mean value of $43 \pm 15 \mu \mathrm{g} \mathrm{C} \mathrm{l}^{-1} \mathrm{~d}^{-1}$. Overall, the production estimates from these 2 approaches were significantly correlated $\left(R^{2}=0.66, p<0.0001\right)$.

\section{Microzooplankton carbon consumption}

Over the wide range of conditions in our study, potential grazer biomass was significantly correlated with autotrophic carbon biomass and with autotrophic daily consumption rate (Fig. 6a,b). In addition, estimates of autotrophic consumption (G-Auto) by protistan grazers during the study showed a temporally variable trophic coupling that reflected changes in size classes (Fig. 6c). High rates of consumption, mostly observed during September 2007 and April 2008, were associated with higher biomass 
Table 1. Estimates of instantaneous growth $(\mu)$ rates, grazing $(m)$ rates $\left(\mathrm{d}^{-1}\right)$, doublings $\left(\mathrm{Dbl}\right.$.) $\left(\mathrm{d}^{-1}\right)$ and averages for total phytoplankton community (Total Phyto, based on total chl a) and for taxon-specific autotrophic groups calculated from dilution experiments conducted at ENSENADA station. Rates were based on cell abundances by flow cytometry analysis for Pro, Syn and P-Euks. Rates were based on taxon-specific pigments for Cryp (alloxanthin-based), Pras (prasinoxanthin-based), Prym (19'-hexanoyloxyfucoxanthin-based) and diatoms (fucoxanthin-based). See Fig. 4 for abbreviations. The $\mu<0$, which were approximated to 0 for average estimations, are italicized; na: not applicable

\begin{tabular}{|c|c|c|c|c|c|c|c|c|c|c|c|c|c|c|c|c|c|c|c|c|c|c|c|}
\hline \multirow{2}{*}{$\begin{array}{l}\text { Depth } \\
\text { (m) }\end{array}$} & \multirow{2}{*}{\multicolumn{2}{|c|}{$\begin{array}{l}\text { Total Phyto } \\
\mu \quad m \text { Dbl. }\end{array}$}} & \multicolumn{3}{|c|}{- Pro -} & \multicolumn{3}{|c|}{- Syn -} & \multicolumn{3}{|c|}{-P-Euks - } & \multicolumn{3}{|c|}{$-\operatorname{Cryp}-$} & \multicolumn{3}{|c|}{- Pras -} & \multicolumn{3}{|c|}{ - Prym -} & \multicolumn{3}{|c|}{ —Diatom - } \\
\hline & & & $\mu$ & $m$ & Dbl. & $\mu$ & & Dbl. & $\mu$ & & Dbl. & $\mu$ & $m$ & Dbl. & $\mu$ & $m$ & Dbl. & $\mu$ & $m$ & Dbl. & $\mu$ & $m$ & Dbl. \\
\hline \multicolumn{24}{|c|}{ Sep `07 } \\
\hline 2 & 1.4 & 0.92 .1 & 0.4 & 0.6 & 0.6 & 0.8 & 0.7 & 1.1 & 1.0 & 1.1 & 1.5 & 0.5 & 0.0 & 0.8 & 0.3 & 0.3 & 0.5 & 0.4 & 0.1 & 0.6 & 1.2 & 0.6 & 1.8 \\
\hline 7 & 1.6 & 2.62 .3 & 0.5 & 0.3 & 0.7 & 1.0 & 0.7 & 1.5 & 1.1 & 0.8 & 1.6 & 0.2 & 0.7 & 0.3 & 0.3 & 1.2 & 0.4 & 0.3 & 1.0 & 0.5 & 1.6 & 2.8 & 2.3 \\
\hline 10 & 1.5 & $0.0 \quad 2.1$ & 0.3 & 0.5 & 0.4 & 1.2 & 0.5 & 1.8 & 1.3 & 0.4 & 1.9 & 0.4 & 0.0 & 0.6 & 0.7 & 0.0 & 1.0 & 0.3 & 0.0 & 0.5 & 2.1 & 0.0 & 3.0 \\
\hline 35 & 0.4 & 0.80 .6 & 1.3 & 1.3 & 1.9 & 1.2 & 0.6 & 1.7 & 0.7 & 0.4 & 0.9 & -0.4 & 0.0 & na & 0.0 & 0.0 & na & 0.0 & 0.0 & na & -0.2 & 0.0 & na \\
\hline \multicolumn{24}{|c|}{ Nov` 07} \\
\hline 10 & 0.7 & 0.41 .0 & 0.4 & 0.5 & 0.5 & 0.6 & 0.6 & 0.9 & 0.6 & 0.4 & 0.9 & 0.2 & 0.3 & 0.4 & 0.6 & 0.3 & 0.9 & 0.3 & 0.0 & 0.5 & 0.6 & 0.2 & 0.8 \\
\hline 20 & 1.2 & 0.81 .8 & 0.4 & 0.6 & 0.5 & 0.4 & 0.5 & 0.6 & 0.4 & 0.6 & 0.6 & 0.3 & 0.0 & 0.4 & 0.7 & 0.3 & 1.0 & 0.6 & 0.2 & 0.8 & 0.8 & 0.3 & 1.1 \\
\hline 30 & 0.7 & 1.01 .0 & 0.1 & 0.2 & 0.1 & 0.2 & 0.4 & 0.3 & 0.4 & 0.4 & 0.5 & -0.1 & 0.0 & na & 0.1 & 0.3 & 0.2 & 0.0 & 0.2 & 0.0 & 0.3 & 0.5 & 0.5 \\
\hline \multicolumn{24}{|c|}{ Jan `08 } \\
\hline 5 & 0.2 & $\begin{array}{ll}0.5 & 0.4\end{array}$ & 0.2 & 0.5 & 0.3 & 0.3 & 0.5 & 0.4 & 0.4 & 0.8 & 0.5 & -0.3 & 0.0 & na & 0.1 & 0.1 & 0.2 & 0.0 & 0.1 & na & 0.1 & 0.0 & 0.1 \\
\hline 20 & 0.3 & 0.70 .4 & 0.2 & 0.4 & 0.3 & 0.4 & 0.5 & 0.6 & 0.2 & 0.7 & 0.3 & 0.1 & 0.5 & 0.1 & 0.1 & 0.4 & 0.2 & 0.1 & 0.5 & 0.1 & 0.1 & 0.4 & 0.2 \\
\hline 30 & 1.5 & 0.42 .1 & 0.4 & 0.7 & 0.6 & 0.6 & 0.7 & 0.9 & 0.7 & 0.6 & 1.0 & 1.1 & 0.0 & 1.6 & 1.2 & 0.2 & 1.7 & 1.1 & 0.0 & 1.6 & 1.0 & 0.0 & 1.4 \\
\hline \multicolumn{24}{|c|}{ Apr ‘08 } \\
\hline 5 & 1.6 & $0.4 \quad 2.3$ & - & - & - & 0.6 & 0.5 & 0.9 & 0.7 & 0.6 & 1.0 & 1.1 & 0.2 & 1.6 & 0.8 & 0.5 & 1.2 & 0.8 & 0.0 & 1.2 & 1.1 & 0.3 & 1.6 \\
\hline 10 & 0.4 & 1.30 .5 & - & - & - & 0.7 & 0.5 & 1.0 & 0.7 & 0.5 & 1.0 & -0.1 & 0.7 & na & 0.6 & 0.8 & 0.8 & -0.2 & 0.6 & na & 0.2 & 1.1 & 0.2 \\
\hline 15 & 0.6 & 0.30 .9 & - & - & - & 0.0 & 0.2 & 0.1 & 0.2 & 0.4 & 0.3 & 0.1 & 0.0 & 0.2 & 0.6 & 1.1 & 0.8 & 0.0 & 0.0 & na & 0.5 & 0.2 & 0.7 \\
\hline \multicolumn{24}{|c|}{ Aug ‘08 } \\
\hline $5-$ & -0.1 & 0.0 na & 0.1 & 0.1 & 0.1 & 0.2 & 0.3 & 0.3 & 0.1 & 0.1 & 0.2 & -0.4 & 0.0 & na & 0.1 & 1.2 & 0.1 & -0.3 & 0.0 & na & 0.1 & 0.0 & 0.1 \\
\hline 10 & 1.2 & $0.7 \quad 1.8$ & 0.9 & 0.5 & 1.3 & 0.7 & 0.5 & 0.9 & 0.4 & 0.3 & 0.6 & 0.5 & 0.0 & 0.7 & 0.9 & 0.5 & 1.3 & 0.7 & 0.2 & 1.0 & 0.8 & 0.3 & 1.1 \\
\hline 20 & 1.0 & 0.71 .5 & 2.1 & 1.5 & 3.0 & 2.1 & 1.4 & 3.0 & 1.5 & 1.2 & 2.2 & - & - & - & - & - & - & - & - & - & - & - & - \\
\hline \multicolumn{24}{|c|}{ Nov` 08} \\
\hline 5 & 0.7 & 0.61 .0 & 0.7 & 0.5 & 1.0 & 0.7 & 0.5 & 1.0 & 0.9 & 0.7 & 1.4 & 0.5 & 0.4 & 0.7 & 0.3 & 0.4 & 0.4 & 0.3 & 0.3 & 0.5 & 0.8 & 0.4 & 1.1 \\
\hline 12 & 1.1 & 0.71 .6 & 0.7 & 0.4 & 1.0 & 0.6 & 0.4 & 0.9 & 0.5 & 0.7 & 0.7 & 1.0 & 0.5 & 1.4 & 0.8 & 0.4 & 1.1 & 0.9 & 0.4 & 1.2 & 0.8 & 0.4 & 1.1 \\
\hline 30 & 0.9 & $0.8 \quad 1.2$ & 0.7 & 0.4 & 1.0 & 0.8 & 0.7 & 1.2 & 0.7 & 0.4 & 1.0 & -0.1 & 0.0 & na & 1.6 & 1.2 & 2.3 & 0.2 & 0.1 & 0.3 & 0.1 & 0.0 & 0.1 \\
\hline Mean & 0.9 & $0.7 \quad 1.4$ & 0.6 & 0.6 & 0.8 & 0.7 & 0.6 & 1.0 & 0.7 & 0.6 & 0.9 & 0.3 & 0.2 & 0.7 & 0.5 & 0.5 & 0.8 & 0.3 & 0.2 & 0.7 & 0.7 & 0.4 & 1.0 \\
\hline SE & 0.1 & $\begin{array}{lll}0.1 & 0.2\end{array}$ & 0.1 & 0.1 & 0.2 & 0.1 & 0.1 & 0.2 & 0.1 & 0.1 & 0.1 & 0.1 & 0.1 & 0.2 & 0.1 & 0.1 & 0.1 & 0.1 & 0.1 & 0.1 & 0.1 & 0.2 & 0.2 \\
\hline
\end{tabular}

of larger consumers (ciliates and flagellates $>20 \mu \mathrm{m}$ ). Lower consumption rates during other periods were associated with assemblages of smaller grazers (Fig. 6c). Complementary shifts in protistan grazer types that match with the dominant phytoplankton are also suggested by significant correlations $(p<$ 0.05 ) between potential grazers classified by size with carbon biomasses and daily consumption rates of different phytoplankton groups (Tables $2 \& 3$ ).

\section{Grazing impact assessments on autotrophic groups}

With the exception of 2 experiments in September 2007 and August 2008, when growth and/or grazing rates for TChl $a$ and consequently G:PP ratios were 0 , microzooplankton grazing showed substantial protistan removal of autotrophic cells throughout the year (Fig. 7a). Overall, protistan consumption (based on individual G:PP ratios) averaged $0.78 \pm 0.09$ for total Auto-C (mean $\pm \mathrm{SE}, \mathrm{n}=19$ ). Higher predatory pressure (i.e. G:PP > 1) was mostly observed during early autumn-winter cruises (September 2007 to January 2008) and in the subsurface chlorophyll maximum in April 2008 (Fig. 7a).

For the whole study period, taxon-specific losses of production to microzooplankton grazing were highest, on average, for Pro $(>100 \pm 6 \%)$ followed by P-Euks (96 $\pm 6 \%)$, Syn $(93 \pm 5 \%)$, prasinophytes $(87 \pm$ $10 \%)$, Other A-Euks $(78 \pm 13 \%)$, diatoms $(45 \pm 11 \%)$, prymnesiophytes $(39 \pm 13 \%)$ and cryptophytes $(30 \pm$ $11 \%$ ) (Fig. 7b,c). High predatory pressure on diatoms and Other A-Euks was mostly observed at the SCM depth in September 2007 and April 2008. During January 2008, both large food items and small autotrophic prey, such as cyanobacteria, P-Euks, prymnesiophytes, cryptophytes and prasinophytes, were strongly consumed at depths $<20 \mathrm{~m}$ (Fig. 7b,c). 

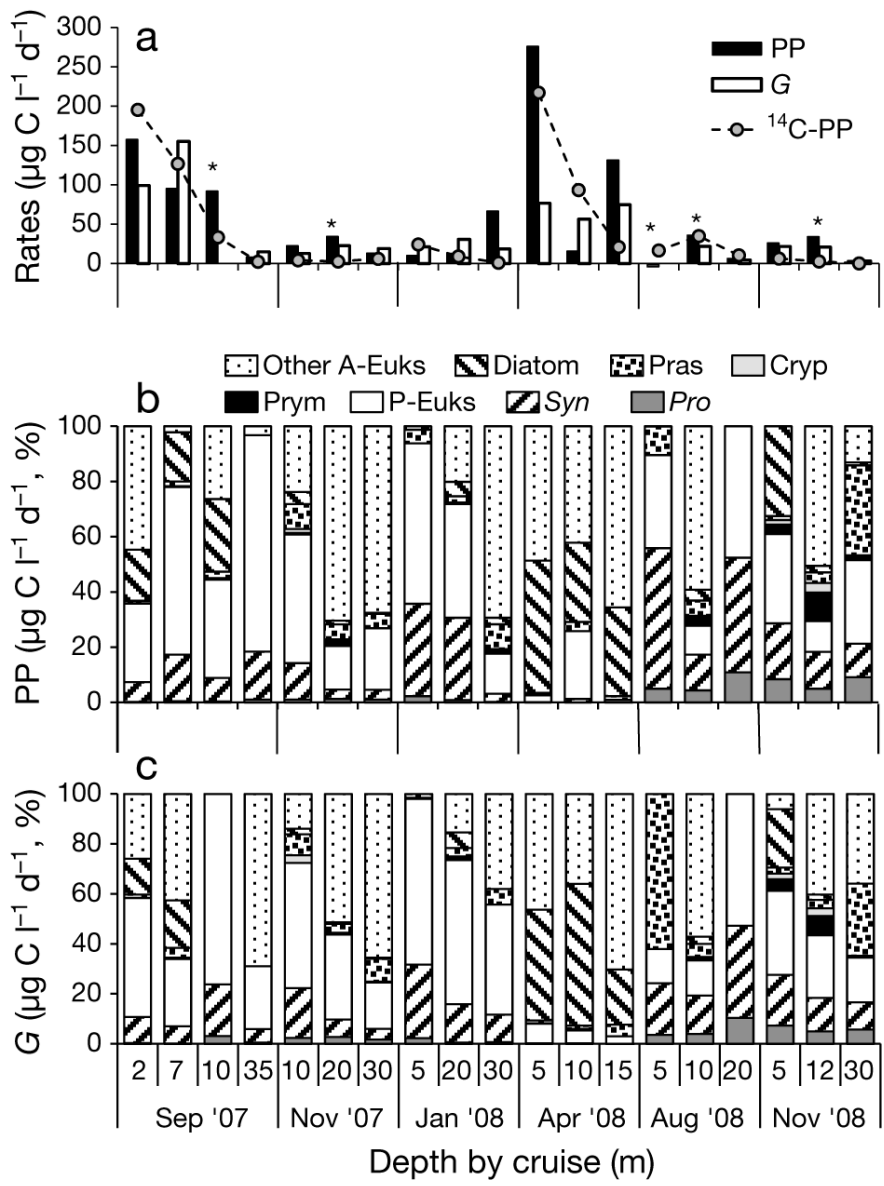

Fig. 5. (a) Daily rates of primary production (PP) and grazing losses $(G)$ by microzooplankton based on total concentration of chlorophyll a (TChl a) and standard measurements of primary production from ${ }^{14} \mathrm{C}$ uptake experiments $\left({ }^{14} \mathrm{C}\right.$-PP). ${ }^{*}$ Deviations of linearity in rate calculations. (b) Relative contribution to total primary production and (c) to total consumption rate by microzooplankton of major phytoplankton groups based on taxon-specific cell counts or pigment concentrations from dilution experiments conducted in the euphotic zone from September 2007 to November 2008 at ENSENADA station. See Fig. 4 and Table 1 for abbreviations

\section{DISCUSSION}

ENSENADA station is considered representative of the dynamic physical and chemical conditions for the northern coastal region off WBC (Linacre et al. 2010b), and the 6 contrasting environmental circumstances that we sampled during the present study are a reasonable reflection of the range of variability that characterizes this area. Upwelling events, which occur more frequently and are stronger during spring and summer in the $\mathrm{BC}$ region (Durazo et al. 2010), are a major environmental feature of this coastal station, being associated with high nutrient delivery and enhanced primary production. During our study, the 2 most productive periods were September 2007 and April 2008 (Fig. 5a), when strong upwelling occurred (Linacre et al. 2010a, see their Fig. 2a). In addition, most of our samplings were conducted during La Niña conditions from early 2007 through early summer 2008 (McClatchie et al. 2008, Durazo 2009). This cold ENSO phase brings the pycnocline and nutricline closer to the ocean surface, favoring entrainment of nutrients into the upper euphotic zone by upwelling favorable winds. During spring of 2008, this event was strongly detected at ENSENADA station, where anomalously cold $\left(\sim 12^{\circ} \mathrm{C}\right)$ and salty $(\sim 33.8)$ seawater, with low dissolved oxygen content $\left(\sim 150 \mu \mathrm{mol} \mathrm{l}^{-1}\right)$ and high dissolved inorganic carbon $\left(\sim 2115 \mu \mathrm{mol} \mathrm{kg}{ }^{-1}\right)$, occurred in the upper $30 \mathrm{~m}$ (Linacre et al. 2010b). Thus, the normal seasonality of the phytoplankton community may have been especially intensified in April 2008 in terms of autotrophic biomass, community structure and production rate.

\section{Plankton community structure}

In general, the biomass of $<200 \mu \mathrm{m}$ plankton in the present study showed an overall close balance between autotrophic and heterotrophic components (Auto-C mean $\pm \mathrm{SE}=48 \pm 10 \mu \mathrm{g} \mathrm{Cl}^{-1}$, Hetero-C mean $\pm \mathrm{SE}=36 \pm 5 \mu \mathrm{g} \mathrm{C}^{-1}$ ). However, autotrophs notably dominated over heterotrophs during the intensified upwelling conditions of April 2008 (Hetero-C to Auto$\mathrm{C}$ ratio $\sim 1: 5)$, when carbon biomass consisted mainly $(>80 \%)$ of chain-forming and large single-celled diatoms (Figs. 2a \& 4a). The upward displacement of upwelling water and the anomalously dense surface water during April 2008 could have physically helped to maintain large and heavy diatoms (some $>50 \mu \mathrm{m}$ ) in the well-lit euphotic zone (Rodríguez et al. 2001).

Similar seasonal trends have been observed in other coastal upwelling systems, where large increases in plankton biomass follow strong upwelling events (Sherr et al. 2005, 2006, Vargas et al. 2007, Teixeira et al. 2011). Our Auto-C biomass values are comparable to those in a $3 \mathrm{yr}$ study conducted off of Oregon (Auto-C averaged $130 \pm 170 \mu \mathrm{g} \mathrm{C} \mathrm{l}^{-1}$ in spring-summer and $41 \pm 44 \mu \mathrm{g} \mathrm{Cl}^{-1}$ in winter; Sherr et al. 2006), but they are lower than those found for a coastal embayment in the NW Iberian upwelling system (Total-C dominated by autotrophs $\sim 100 \mu \mathrm{g} \mathrm{C} \mathrm{l^{-1 }}$ in winter and $\sim 800 \mu \mathrm{g} \mathrm{C} \mathrm{l}^{-1}$ in summer-early autumn; Teixeira et al. 2011). In this latter study, diatoms were always present and accounted for a large fraction of Auto-C. In contrast, diatoms played a seasonally variable role at our coastal site (Fig. 4a). 

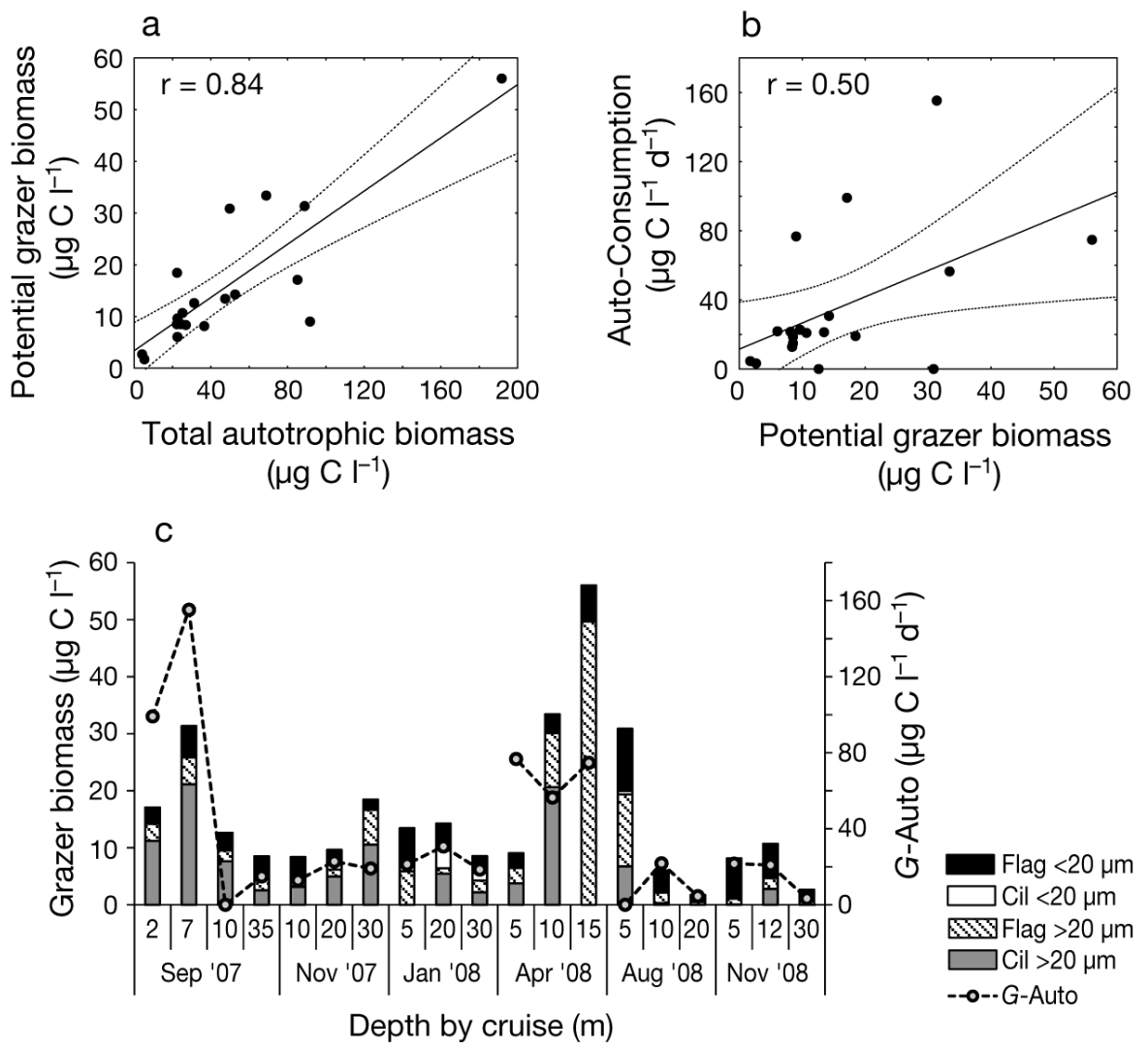

Fig. 6. Product-moment correlation between (a) potential grazer and total autotrophic biomasses and (b) daily rate of total autotrophic consumption and potential grazer biomass. Dotted lines indicate $95 \%$ CI. (c) Relative initial carbon biomass of microzooplankton grazers by size (left axis): ciliates $<20$ and $>20 \mu \mathrm{m}$ (Cil $<20 \mu \mathrm{m}$ and Cil $>20 \mu \mathrm{m}$, respectively) and mixotrophic flagellates (including dinoflagellates) $<20$ and $>20 \mu \mathrm{m}$ (Flag $<20 \mu \mathrm{m}$ and Flag $>20 \mu \mathrm{m}$, respectively), in addition to microzooplankton consumption estimates (right axis) on autotrophic organisms (G-auto), with data estimated from dilution experiments conducted in the euphotic zone from September 2007 to November 2008 at ENSENADA station. Both correlations are statistically significant at $\mathrm{p}<0.05$

On average, autotrophic pico-sized cells accounted for $57 \%$ of total phytoplankton biomass, except in April 2008, when they comprised $<10 \%$ (Fig. 3a). Similarly, H-Bact accounted for $75 \%$ of the total Hetero-C during most of our samplings (Fig. 3b).
Taylor et al. (2011) reported mean euphotic-zone estimates of $37 \%$ (ranging from 16 to $65 \%$ ) and $58 \%$ of total autotrophic and heterotrophic carbon for phototrophic bacteria and $\mathrm{H}$-Bact, respectively, in eastern equatorial Pacific waters. We consequently found biomass structure similar to the open ocean at our coastal upwelling site for most of the study period. In coastal waters off ENSENADA station, a large part of the variability during summer/autumn and winter is due to the seasonality of circulation patterns off southern California and northern BC. Among the patterns, surface and subsurface waters flow poleward in a narrow coastal band, linked to the California Current (CC) cyclonic recirculation and the permanent northern subsurface cyclonic eddy (Linacre et al. 2010b). Thus, the meandering CC brings waters with more oceanic influence (i.e. more oligotrophic conditions) to our coastal site by recirculation during most of the year, carrying populations of smaller cells better adapted to low-nutrient conditions, as suggested by a negative relationship between log-abundance of A-Pico cells and euphotic zone nitrate + nitrite concentrations (Linacre et al. 2010a, their Fig. 10). Nutrient concentrations are low in the upper $10 \mathrm{~m}$ during the summer/autumn and winter sampling periods (mostly $\left[\mathrm{NO}_{3}^{-}+\mathrm{NO}_{2}^{-}\right]<2 \mu \mathrm{M}$ and $\left[\mathrm{Si}(\mathrm{OH})_{4}\right]<5 \mu \mathrm{M}$, data not shown), as expected for these seasons of the year in the southern $\mathrm{CC}$ system.

Table 2. Product-moment correlations between total and taxon-specific carbon biomasses of phytoplankton with carbon biomasses of total potential grazers and nano/micro-flagellates (Flag $<20$ and $>20 \mu \mathrm{m}$, respectively, including dinoflagellates) and nano/micro-ciliates (Cil, $<20$ and $>20 \mu \mathrm{m}$, respectively), from initial samples collected during the dilution experiments conducted from September 2007 to November 2008 at ENSENADA station. Significant correlations at $\mathrm{p}<0.05$ in bold; $\mathrm{n}=19$ (number of experiments). Abbreviations as in Fig. 4

\begin{tabular}{|lrrrrrrrrr|}
\hline & Total Auto-C & Pro & Syn & P-Euks & Prym & Cryp & A-Flag & Diatom & A-Dino \\
\hline Total Grazers & $\mathbf{0 . 8 4}$ & -0.02 & 0.06 & 0.16 & 0.27 & -0.13 & 0.39 & $\mathbf{0 . 6 1}$ & $\mathbf{0 . 8 1}$ \\
Nano-Flag & 0.33 & $\mathbf{0 . 6 8}$ & $\mathbf{0 . 4 7}$ & 0.14 & $\mathbf{0 . 8 1}$ & 0.37 & $\mathbf{0 . 4 8}$ & 0.06 & 0.27 \\
Micro-Flag & $\mathbf{0 . 8 3}$ & -0.12 & -0.19 & -0.15 & 0.29 & -0.18 & 0.21 & $\mathbf{0 . 6 6}$ & $\mathbf{0 . 9 8}$ \\
Nano-Cil & -0.08 & -0.02 & 0.33 & 0.31 & -0.05 & -0.08 & 0.01 & -0.24 & -0.14 \\
Micro-Cil & 0.21 & -0.09 & 0.23 & $\mathbf{0 . 4 9}$ & -0.22 & -0.08 & 0.26 & 0.14 & -0.09 \\
\hline
\end{tabular}


Table 3. Product-moment correlations between total and taxon-specific daily grazing losses of phytoplankton $(G)$ with carbon biomasses of total potential grazers and nano/micro-flagellates (Flag, $<20 \mu \mathrm{m}$ and $>20 \mu \mathrm{m}$, respectively, including dinoflagellates) and nano/micro-ciliates (Cil, $<20 \mu \mathrm{m}$ and $>20 \mu \mathrm{m}$, respectively) from data collected during the dilution experiments conducted from September 2007 to November 2008 at ENSENADA station. Significant correlations at $\mathrm{p}<0.05$ in bold $\mathbf{b}_{i}=\mathrm{number}$ of experiments. Other A-Euks: autotrophic eukaryotes in other taxa; other abbreviations as in Fig. 4 and Table 1

\begin{tabular}{|lrrrrrrrrr|}
\hline & $\begin{array}{c}\text { G-Auto } \\
(\mathrm{n}=19)\end{array}$ & $\begin{array}{c}\text { G-Syn } \\
(\mathrm{n}=19)\end{array}$ & $\begin{array}{c}\text { G-Pro } \\
(\mathrm{n}=16)\end{array}$ & $\begin{array}{c}\text { G-P-Euks } \\
(\mathrm{n}=19)\end{array}$ & $\begin{array}{c}\text { G-Prym } \\
(\mathrm{n}=18)\end{array}$ & $\begin{array}{c}\text { G-Cryp } \\
(\mathrm{n}=18)\end{array}$ & $\begin{array}{c}\text { G-Pras } \\
(\mathrm{n}=18)\end{array}$ & $\begin{array}{r}\text { G-Diatom } \\
(\mathrm{n}=18)\end{array}$ & $\begin{array}{c}\text { G-Other A-Euks } \\
(\mathrm{n}=16)\end{array}$ \\
\hline Total Grazers & $\mathbf{0 . 5 0}$ & 0.04 & -0.19 & 0.13 & -0.10 & -0.16 & $\mathbf{0 . 6 1}$ & $\mathbf{0 . 4 7}$ & $\mathbf{0 . 7 3}$ \\
Nano-Flag & 0.06 & 0.23 & 0.39 & 0.01 & 0.32 & 0.25 & $\mathbf{0 . 6 7}$ & -0.04 & 0.22 \\
Micro-Flag & 0.25 & -0.22 & -0.15 & -0.16 & -0.19 & -0.21 & 0.38 & 0.25 & $\mathbf{0 . 5 4}$ \\
Nano-Cil & -0.16 & 0.15 & -0.25 & 0.10 & -0.06 & -0.16 & -0.08 & -0.30 & -0.33 \\
Micro-Cil & $\mathbf{0 . 6 1}$ & 0.36 & -0.32 & $\mathbf{0 . 5 1}$ & 0.03 & -0.04 & 0.34 & $\mathbf{0 . 6 0}$ & $\mathbf{0 . 5 1}$ \\
\hline
\end{tabular}
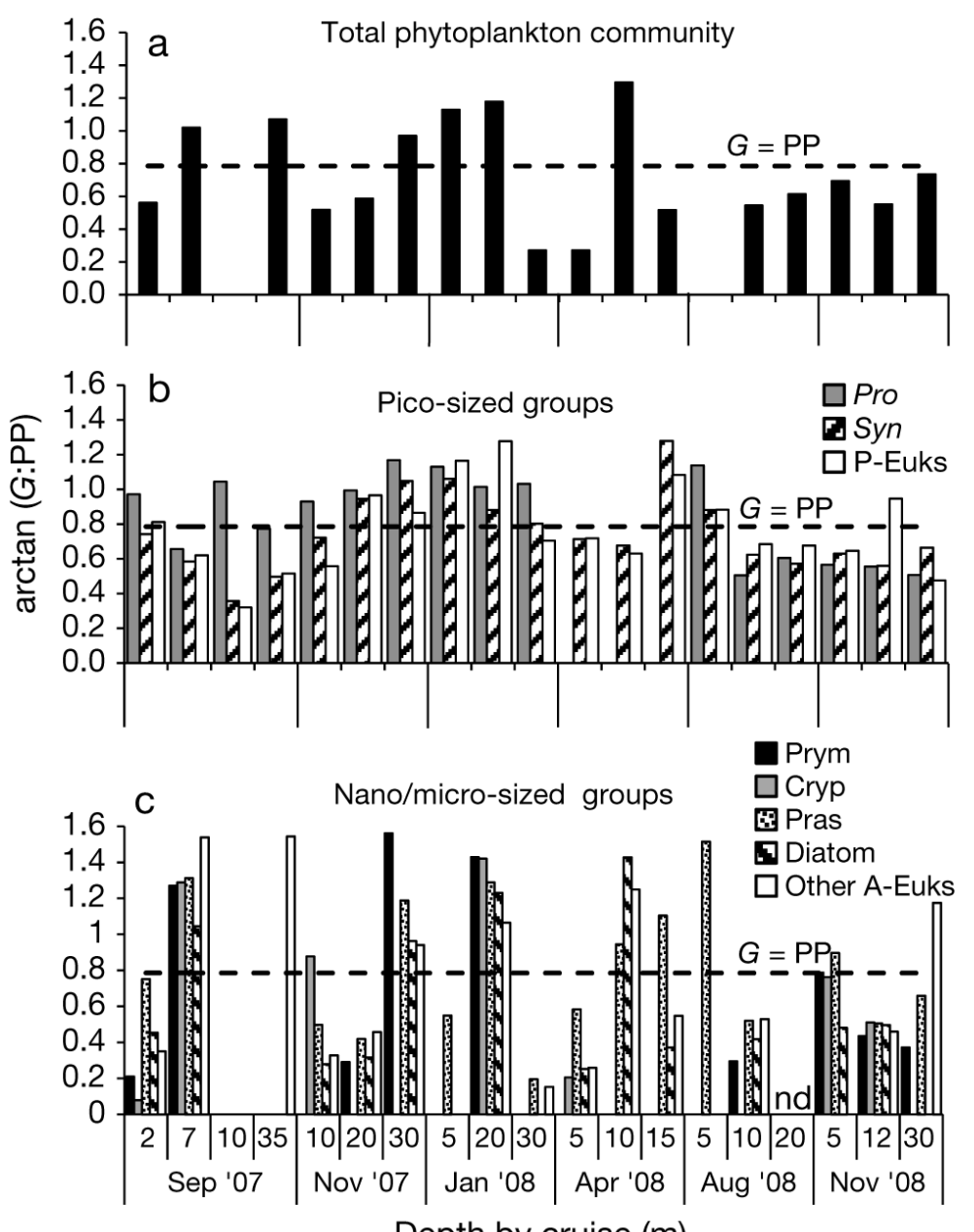

Fig. 7. Arctangent ratio of daily protistan consumption $(G)$ to production (PP) for (a) total phytoplankton community (TChl abased), (b) picophytoplankton groups (cell-based) and (c) major nano- and micro-sized groups (pigment-based), with data estimated from dilution experiments conducted from September 2007 to November 2008 at ENSENADA station. Horizontal dashed lines indicate the ratio when grazing losses are equal to daily primary production $(G=\mathrm{PP})$; nd: no data; see Fig. 4 and Table 1 for other abbreviations
Relatively high bacterial abundances (mean $\pm \mathrm{SE}=1.29 \pm 0.16 \times 10^{6} \mathrm{cell} \mathrm{ml}^{-1}$ ) and large car-

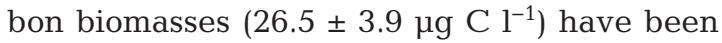
found in other coastal upwelling systems. On average, bacterial abundances and biomass of $1.01 \pm 0.79 \times 10^{6}$ cells ml $^{-1}$ and $30 \pm 24 \mu \mathrm{g} \mathrm{C}{ }^{-1}$, respectively, were reported for the upper $50 \mathrm{~m}$ in the Oregon upwelling system (Sherr et al. 2006). Similarly, abundances $>10^{6}$ cells $\mathrm{ml}^{-1}$ and depth-integrated bacterial biomasses of 1067 to $1579 \mathrm{mg} \mathrm{C} \mathrm{m}^{-2}$ (our depth-integrated range was 138 to $1123 \mathrm{mg} \mathrm{C} \mathrm{m}^{-2}$ ) were reported for shallow water $(<50 \mathrm{~m}$ depth) under generally non-upwelling conditions in the Humboldt Current system (Cuevas et al. 2004). The large carbon contribution of H-Bact reflects, in part, our higher cell carbon estimates (16 to $24 \mathrm{fg} \mathrm{C}$ cell $^{-1}$ ) compared to a more conservative estimate of $11 \mathrm{fg} \mathrm{C}$ cell $^{-1}$ used for open-ocean studies (Garrison et al. 2000, Landry \& Kirchman 2002, Brown et al. 2008). However, our carbon conversion factors are quite comparable to other values used in coastal ecosystems (carbon per cell from 20 to $30 \mathrm{fg} \mathrm{C} \mathrm{Cell}^{-1}$; e.g. Cuevas et al. 2004, Sherr et al. 2006, Teixeira et al. 2011). Thus, in comparison, the H-Bact biomass values in the present study are reasonable, if not conservative.

\section{Carbon fluxes through the microbial plankton community}

Under varying physical-chemical characteristics of the water column at ENSENADA station, the community and major phytoplankton groups displayed high variability in their production and grazing daily rates. Expressed as carbon fluxes, these rates reflect variability in 
both the specific rates, inferred from pigment and cell-abundance measurements, and the estimated carbon biomasses of the phytoplankton assemblage and individual groups. Our estimates of the C:TChl $a$ ratio for the phytoplankton community were moderate, ranging from 5 to 41 , with a mean $( \pm 1 \mathrm{SE})$ value of $25 \pm 2$. This is in the range reported for other coastal waters with similar nutrient concentrations and light conditions (Eppley 1968, Arin et al. 2002, Gutiérrez-Rodríguez et al. 2010). Arin et al. (2002) noted that higher $\mathrm{C}$ :chl a ratios tend to be associated with larger cell size, which seems to be consistent with our ratio estimate $(\sim 40)$ found in the $15 \mathrm{~m}$ sample from April 2008 (Fig. 2a), dominated by large autotrophic dinoflagellates $(>50 \%$ of cells $>20 \mu \mathrm{m}$; Fig. 4a). However, high C:TChla ratios were also seen during other periods when small cells were dominant (e.g. January 2008). This seems to suggest, as in Gutiérrez-Rodríguez et al. (2010), that the influence of nutrient availability and irradiance on cellular pigment content prevails over cell size in our C:TChl a values.

Comparing our dilution-based estimates of phytoplankton production with the standard measurements of PP by net ${ }^{14} \mathrm{C}$ uptake, we found a similar range in magnitude (from 0 to $276 \mu \mathrm{g} \mathrm{C}^{-1} \mathrm{~d}^{-1}$ for

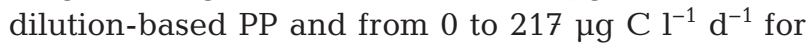
${ }^{14} \mathrm{C}-\mathrm{PP}$ ), a similar seasonal variability (highest values in spring and lowest in winter/autumn periods) and a significant correlation between the 2 rates $\left(R^{2}=0.66\right.$, $\mathrm{p}<0.0001$ ) (Fig. 5a). This close association of PP estimates based on different methodologies lends support to our taxon-specific flux inferences, which sum to total community production.

In general, we found a close production-consumption coupling at our coastal site. Higher PP and G estimations were measured in September 2007 and April 2008, associated with higher phytoplankton standing stocks and growth/grazing rates of dominant groups. Conversely, during the other periods, lower estimations derived from lower carbon biomasses and rates were found in association with more oligotrophic conditions (Table 1, Fig. 5a). This coupled trophic pattern has also been shown for other coastal systems (Strom et al. 2001, McManus et al. 2007, Landry et al. 2009, Gutiérrez-Rodríguez et al. 2010, Teixeira et al. 2011). For such systems, it appears that adjustments in the coupling of grazing interactions to temporal fluctuations of phytoplankton standing stock and production through a flexible multivorous food web (herbivorous and microbial trophic modes) contribute to efficient carbon cycling within the upper ocean (Legendre \& Rassoulzadegan 1995).
Trophic coupling between carbon production and grazing loss can be estimated among the major autotrophic groups based on their specific contributions to biogenic carbon fluxes (Fig. 5b,c). Linacre et al. (2010a) noted that auto- and heterotrophic picoplankton generally constitute important community components at the ENSENADA station (Fig. 3). According to our estimates, A-Pico generally account for $>50 \%$ of primary production, of which $94 \%$, on average, is consumed daily by microzooplankton grazers during most of the year (Fig. 5b,c). In spite of seasonal variations, a close net growth/grazing balance was generally found for this size category, as has been documented for equatorial Pacific waters (Landry et al. 2011), and other coastal ecosystems (Strom et al. 2001, 2007, Worden et al. 2004). Although prasinophytes are an important group of small green algae further to the north in the CC system according to microscopic (Thomsen \& Buck 1998) and molecular analyses (Worden et al. 2004, Worden 2006), they seem to contribute a minor fraction to carbon fluxes in the ENSENADA station. However, it is important to remark that not only nano- but also pico-sized cells, such as Ostreococcus, belong to this group (Worden et al. 2004). Thus, some of the carbon balance attributed to P-Euks cells might be due to pico-prasinophytes (Fig. 5b,c).

The largest fractions of $\mathrm{C}$ production and $\mathrm{C}$ losses to grazing for both diatoms and other nano/micro-sized autotrophic-eukaryotes (Other A-Euks, mainly dinoflagellates) occurred in April 2008 (>80\% of PP and $\sim 80 \%$ of daily consumption for both large-sized groups), when exceptionally high values of carbon

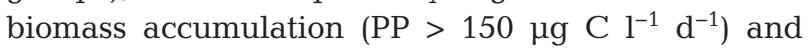
large ciliate grazers were observed in the euphotic zone (Figs. 5a \& 6c). Diatoms experienced lower predatory pressure by microzooplankton on average relative to small autotrophic cells ( $G$ :PP mean $\pm \mathrm{SE}=$ $46 \pm 10 \%$ ) throughout the study period, leaving about half of diatom production for mesozooplankton consumption or export due to lateral advection or sinking. Similar microzooplankton grazing impacts on diatoms were recorded in the NW Iberian upwelling system ( $G: P P$ mean $\pm \mathrm{SD}=45 \pm 31 \%$; Teixeira et al. 2011) and in the upwelling region of the Humboldt current system off Chile (25 to $45 \%$ of diatom PP during winterautumn and 11 to $18 \%$ PP in spring-summer; Vargas et al. 2007). Total carbon and diatom losses to mesozooplankton grazing were not estimated at our coastal station. However, for the upwelling system off southern California, Landry et al. (2009) found a variable contribution of mesozooplankton relative to the microzooplankton grazing impact on whole autotrophic 
community (chl a-based) that increased in inshore waters during springtime, suggesting strong topdown control by this size category of grazers. Thus, a large part of diatom production that is not consumed directly by microherbivores at our coastal site is likely consumed by mesozooplankton, with more efficient transfer to higher trophic levels (fish).

The dynamics of carbon production and grazing loss by microzooplankton in the euphotic zone of the ENSENADA station indicate that biogenic carbon flows occur mainly through microbial components of the food web, including larger phytoplankton cells consumed by protists. Such multivorous food webs are intermediate between the traditional herbivorous and microbial food webs. Based on Legendre \& Rassoulzadegan's (1996) approaches that use ecological ratios, such as small-sized $(<5 \mu \mathrm{m})$ to large-sized $(>5 \mu \mathrm{m})$ phytoplankton production $\left(\mathrm{PP}_{\mathrm{S}}: \mathrm{PP}_{\mathrm{L}}\right)$, Mousseau et al. (2001) evaluated planktonic food webs according to 3 trophic pathways corresponding to the herbivorous $\left(\mathrm{PP}_{\mathrm{S}}: \mathrm{PP}_{\mathrm{L}}<1\right)$, multivorous $\left(\mathrm{PP}_{\mathrm{S}}: \mathrm{PP}_{\mathrm{L}}=\right.$ 1.0-4.5) and microbial $\left(\mathrm{PP}_{\mathrm{S}}: \mathrm{PP}_{\mathrm{L}}>4.5\right.$, including microbial loop) consumers. If we consider diatoms and Synechococcus to be representative of large and small autotrophs, respectively, a herbivorous pathway dominated at ENSENADA station in September 2007 and April $2008\left(\mathrm{PP}_{\mathrm{S}}: \mathrm{PP}_{\mathrm{L}}\right.$ ranged from 0 to 0.9 ), associated with more nutrient input by the stronger and frequent upwelling events, large-sized and chain-forming diatoms and strong consumption by large ciliates and mixotrophic flagellates. For the other periods, trophic dominance varied from multivorous (mostly November cruises) to microbial pathways, with $\mathrm{PP}_{\mathrm{S}}: \mathrm{PP}_{\mathrm{L}}$ ratios oscillating between 1.3 and 26.7 (with an extreme value of $\sim 500$ in August 2008 ) in association with low nutrient concentrations, strong stratification, small primary producers and mainly nanograzer groups. These rough approximations indicate that microbial components of the planktonic food web can have significant impacts on carbon fluxes during contrasting environmental conditions in the coastal upwelling system off WBC.

\section{Microzooplankton role in carbon fluxes}

Microzooplankton play a key role as grazers of primary producers and as trophic intermediates to higher levels of marine food webs under most environmental conditions (Calbet \& Landry 2004). As such, the size and composition of the microzooplankton assemblage reflects the differing productivities of pelagic ecosystems (Calbet 2008). Small grazers
$(<20 \mu \mathrm{m})$, such as nanoflagellates, are the main consumers of phytoplankton in oligotrophic waters (Sherr \& Sherr 2002, Calbet 2008), while heterotrophic and mixotrophic dinoflagellates and ciliates are major components in more productive waters (Neuer \& Cowles 1994, Aberle et al. 2007, Sherr \& Sherr 2007, Teixeira et al. 2011).

The microzooplankton consumers at our coastal site seem to be strongly sustained by all types of autotrophic groups (from pico to micro-sized cells), as was evident not only from the high grazing impact (overall mean $\pm \mathrm{SE}=78 \pm 9 \%$ ) on the phytoplankton community and most autotrophic taxa (Fig. 7) but also by significant correlations $(p<0.05)$ between grazer biomass, total autotrophic biomass and daily consumption rates (Fig. 2). Moreover, the relative roles of micrograzers appear to follow the dominance structure in the planktonic food web. The positive and significant biomass correlations found between diatoms and A-Dino with microflagellates and also between prymnesiophytes or cyanobacteria with nanoflagellates (Table 2) suggest a correspondence in the size categories of autotrophic prey and their consumers. This is also indicated by significant correlations between daily consumption rates of some larger and smaller food types with the carbon biomass estimates of micro- and nano-sized grazers, respectively (Table 3). Additionally, temporal variability in the phytoplankton-microzooplankton link by size category is suggested by high predatory pressure on pico- and nanophytoplankton (prasinophytes and prymnesiophytes) associated with the dominance of small ciliates and nanoflagellates in January 2008, while strong grazing on diatoms was measured in September 2007 and April 2008, when large ciliates were major contributors to the microzooplankton biomass (Figs. 6c \& 7b,c).

Large ciliates can be significant consumers of diatom chains and large single-celled diatoms in coastal waters (Aberle et al. 2007, Teixeira et al. 2011). However, diatoms can also be efficiently consumed by heterotrophic dinoflagellates, which prey on cells as large as themselves or even larger (Sherr \& Sherr 2007 and literature therein). Large pigmented dinoflagellates, as well as other flagellates, may also be mixotrophs that contribute to grazing (Sherr \& Sherr 1994, 2002). Thus, the high consumption of diatoms in April 2008 might not only be associated with ciliates but also with large dinoflagellates, such as gymnodinoids, which were particularly evident in microscopy samples at this time. In equatorial Pacific waters, both large dinoflagellates and ciliates responded quickly to an iron-fertilized dia- 
tom bloom (Landry et al. 2000a,b). Large dinoflagellates have also been reported as significant consumers of chain-forming diatoms in other coastal and open-ocean systems (Neuer \& Cowles 1994, StelfoxWiddicombe et al. 2004, Teixeira et al. 2011).

Prymnesiophytes, recently found to be active mixotrophic grazers on Prochlorococcus and Synechococcus in the ocean surface waters of the Pacific Ocean (Frias-Lopez et al. 2009), may also have contributed to the grazing regulation of small prey, notably in August 2008 and November 2008, when high consumption rates on Pro and high biomass and production rates for prymnesiophytes coincided (Figs. 4a \& 5b,c). A significant correlation between Pro and Prym carbon biomasses $(\mathrm{r}=0.71, \mathrm{p}<0.05$, data not shown) was also found for our study period, suggesting a coupling, though not necessarily trophic, between these groups. Within the trophic structure, cascade interactions among consumers could influence the grazing impacts of individual size classes, e.g. by suppressing the activities of smaller grazers when their predators (large ciliates and dinoflagellates) are abundant (Calbet et al. 2008, Chen \& Liu 2010). In subtropical coastal waters, for example, dilution and size-fractionation experiments have revealed trophic linkages among different micrograzers and their small-sized prey (Chen \& Liu 2010). Although a lower biomass of nanoflagellates (including small dinoflagellates) than ciliates was generally observed at our coastal site, we found high grazing impacts on pico/nano-sized cells in some experiments in which nanoflagellate biomass was similar or ever higher than that of large ciliates. Such variability in composition of the grazer assemblage could reflect temporal differences in the top-down regulation of large ciliates by mesozooplankton.

The present results suggest a relatively fast trophic-coupling response in the size structure and composition of the microzooplankton grazer assemblages to temporal variations of appropriately sized prey, which would help to maintain carbon transfer through a multivorous food web. In contrast to the more traditional herbivorous pathway that is often assumed for coastal upwelling systems, the multivorous food web promotes mineral and carbon cycling within the euphotic zone. Consequently, this coastal upwelling system might be surprisingly inefficient in sequestering carbon to export or in transferring production to higher trophic levels.

Acknowledgements. We gratefully acknowledge all of the students, technicians and scientists whose efforts facilitated and contributed to our results, as well as the captain and crew of RV 'Francisco de Ulloa' and the boat 'GENUS' for their help during the hard work at sea. A. Taylor and D. Wick contributed valuable support in training and help with the epifluorescence microscopy analysis and software data processing. We also appreciate the valuable help received from the undergraduate student P. García (FC, $\mathrm{UABC}$ ) with ciliate counting and V. Camacho-Ibar (IIO$\mathrm{UABC}$ ) for the nutrient analysis. The present study was supported by FLUCAR project from CONACyT grants SEP2004-C01-45813/A-1 and 25339, and L.L. was also supported by a CONACyT fellowship (No. 201017; ReMAS 2010-015). M.R.L. was supported by the California Current Ecosystem Program (CCE-LTER; NSF OCE 04-17616 and 10-22607). We are also grateful to 5 anonymous reviewers for their valuable comments that greatly improved this work.

\section{LITERATURE CITED}

Aberle N, Lengfellner K, Sommer U (2007) Spring bloom succession, grazing impact and herbivore selectivity of ciliate communities in response to winter warming. Oecologia 150:668-681

Almazán-Becerril A, García-Mendoza E (2008) Photosystem II maximum efficiency of charge separation of the phytoplankton community in the Eastern Tropical North Pacific (ENTP) off Mexico: A nutrient stress diagnostic tool? Cienc Mar 34:29-43

Arin L, Moran XAG, Estrada M (2002) Phytoplankton size distribution and growth rates in the Alboran Sea (SW Mediterranean): short term variability related to mesoscale hydrodynamics. J Plankton Res 24:1019-1033

Brown SL, Landry MR, Selph KE, Yang EJ, Rii YM, Bidigare RR (2008) Diatoms in the desert: plankton community response to a subtropical mesoscale eddy in the subtropical North Pacific. Deep-Sea Res II 55:1321-1333

> Calbet A (2001) Mesozooplankton grazing effect on primary production: a global comparative analysis in marine ecosystems. Limnol Oceanogr 46:1824-1830

Calbet A (2008) The trophic roles of microzooplankton in marine systems. ICES J Mar Sci 65:325-331

> Calbet A, Landry MR (2004) Phytoplankton growth, microzooplankton grazing and carbon cycling in marine systems. Limnol Oceanogr 49:51-57

Calbet A, Trepat I, Almeda R, Saló V and others (2008) Impact of micro- and nanograzers on phytoplankton assessed by standard and size-fractionated dilution grazing experiments. Aquat Microb Ecol 50:145-156

Chen B, Liu H (2010) Trophic linkages between grazers and ultraplankton within the microbial food web in subtropical coastal waters. Mar Ecol Prog Ser 407:43-53

Colombo-Pallotta MF, García-Mendoza E, Ladah LB (2006) Photosynthetic performance, light absorption, and pigment composition of Macrocystis pyrifera (Laminariales, Phaeophyceae) blades from different depths. J Phycol 42:1225-1234

Cuevas LA, Daneri G, Jacob B, Montero P (2004) Microbial abundance and activity in the seasonal upwelling area off Concepción $\left(\sim 36^{\circ} \mathrm{S}\right)$, central Chile: a comparison of upwelling and non-upwelling conditions. Deep-Sea Res II 51:2427-2440

> Durazo R (2009) Climate and upper ocean variability off Baja California, Mexico: 1997-2008. Prog Oceanogr 83: 361-368 
Durazo R, Ramírez AM, Miranda LE, Soto-Mardones LA (2010) Climatología hidrográfica de la Corriente de California frente a Baja California. In: Gaxiola G, Durazo R (eds) Dinámica del Ecosistema Pelágico frente a Baja California, 1997-2007. Diez años de investigaciones Mexicanas de la Corriente de California. INE-SEMARNAT, Mexico City, p 25-57

- Eppley RW (1968) An incubation method for estimating the carbon content of phytoplankton in natural samples. Limnol Oceanogr 13:574-582

Frias-Lopez J, Thompson A, Waldbauer J, Chisholm S (2009) Use of stable isotope-labelled cells to identify active grazers of picocyanobacteria in ocean surface waters. Environ Microbiol 11:512-525

> Garrison DL, Gowing MM, Huges MP, Campbell L and others (2000) Microbial food web structure in the Arabian Sea: a US JGOFS study. Deep-Sea Res II 47:1387-1422

Gutiérrez-Rodríguez A, Latasa M, Estrada M, Vidal M, Marrasé C (2010) Carbon fluxes through major phytoplankton groups during the spring bloom and post-bloom in the Northwestern Mediterranean Sea. Deep-Sea Res I 57:486-500

Jeffrey SW, Vesk M (1997) Introduction to marine phytoplankton and their pigment signatures. In: Jeffrey SW, Mantoura RCF, Wright SW (eds) Phytoplankton pigments in oceanography: guidelines to modern methods. UNESCO Publishers, Paris, p 37-82

Landry MR, Hassett RP (1982) Estimating the grazing impact of marine microzooplankton. Mar Biol 67:283-288

> Landry MR, Kirchman DL (2002) Microbial community structure and variability in the tropical Pacific. Deep-Sea Res II 49:2669-2693

> Landry MR, Constantinou J, Latasa M, Brown SL, Bidigare RR, Ondrusek ME (2000a) Biological response to iron fertilization in the eastern equatorial Pacific (IronEx II). III. Dynamics of phytoplankton growth and microzooplankton grazing. Mar Ecol Prog Ser 201:57-72

> Landry MR, Ondrusek ME, Tanner SJ, Brown SL and others (2000b) Biological response to iron fertilization in the eastern equatorial Pacific (IronEx II). I. Microplankton community abundances and biomass. Mar Ecol Prog Ser 201:27-42

> Landry MR, Brown SL, Neveux J, Dupouy C, Blanchot J, Christensen S, Bidigare RR (2003) Phytoplankton growth and microzooplankton grazing in high-nutrient, lowchlorophyll waters of the equatorial Pacific: community and taxon-specific rate assessments from pigment and flow cytometric analyses. J Geophys Res 108:8142, doi: 10.1029/2000JC000744

> Landry MR, Brown SL, Rii YM, Selph KE, Bidigare RR, Yang EJ, Simmons MP (2008) Depth-stratified phytoplankton dynamics in Cyclone Opal, a subtropical mesoscale eddy. Deep-Sea Res II 55:1348-1359

- Landry MR, Ohman MD, Goericke R, Stukel MR, Tsyrklevich K (2009) Lagrangian studies of phytoplankton growth and grazing relationships in a coastal upwelling ecosystem off Southern California. Prog Oceanogr 83: 208-216

> Landry MR, Selph KE, Taylor AG, Décima M, Balch WM, Bidigare RR (2011) Phytoplankton growth, grazing and production balances in the HNLC equatorial Pacific. Deep-Sea Res II 58:524-535

> Latasa M, Bidigare RR (1998) A comparison of phytoplankton populations of the Arabian Sea during the spring intermonsoon and southwest monsoon of 1995 as described by HPLC-analyzed pigments. Deep-Sea Res II 45:2133-2170

Latasa M, Moran X, Scharek R, Estrada M (2005) Estimating the carbon flux through main phytoplankton groups in the northwestern Mediterranean. Limnol Oceanogr 50: 1447-1458

> Lee S, Fuhrman J (1987) Relationships between biovolume and biomass of naturally derived marine bacterioplankton. Appl Environ Microbiol 53:1298-1303

Legendre L, Rassoulzadegan F (1995) Plankton and nutrient dynamics in marine waters. Ophelia 41:153-172

> Legendre L, Rassoulzadegan F (1996) Food-web mediated export of biogenic carbon in oceans: hydrodynamic control. Mar Ecol Prog Ser 145:179-193

> Linacre LP, Landry MR, Lara-Lara JR, Hernández-Ayón JM, Bazán-Guzmán C (2010a) Picoplankton dynamics during contrasting seasonal oceanographic conditions at a coastal upwelling station off Northern Baja California, México. J Plankton Res 32:539-557

> Linacre L, Hernández-Ayón JM, Durazo R, Delgadillo-Hinojosa $\mathrm{F}$ and others (2010b) Temporal variability of the physicochemical water characteristics at a coastal monitoring observatory: station ENSENADA. Cont Shelf Res 30:1730-1742

McClatchie S, Goericke R, Koslow JA, Schwing FB and others (2008) The state of the California current, 2007-2008: La Niña conditions and their effects on the ecosystem. CalCOFI Rep 49:39-76

- McManus GB, Costas BA, Dam HG, Lopes RM, Gaeta SA, Susini SM, Rosetta CH (2007) Microzooplankton grazing of phytoplankton in a tropical upwelling region. Hydrobiologia 575:69-81

> Menden-Deuer S, Lessard EJ (2000) Carbon to volume relationships for dinoflagellates, diatoms, and other protist plankton. Limnol Oceanogr 45:569-579

> Mousseau L, Klein B, Legendre L, Dauchez S, Tamigneaux E, Tremblay JE, Ingram R (2001) Assessing the trophic pathway that dominate planktonic food webs: an approach based on simple ecological ratios. J Plankton Res 23:765-777

> Neuer S, Cowles TJ (1994) Protist herbivory in the Oregon upwelling system. Mar Ecol Prog Ser 113:147-162

Parsons TR, Maita Y, Lalli CM (1984) A manual of chemical and biological methods for seawater analysis. Pergamon Press, Oxford

Putt M, Stoecker DK (1989) An experimentally determined carbon:volume ratio for marine 'oligotrichous' ciliates from estuarine and coastal waters. Limnol Oceanogr 34: 1097-1103

Rodríguez J, Tintoré J, Allen J, Blanco JM and others (2001) Mesoscale vertical motion and the size structure of phytoplankton in the ocean. Nature 410:360-363

Sherr EB, Sherr BF (1993) Preservation and storage of samples for enumeration of heterotrophic protists. In: Kemp PF, Cole JJ, Sherr BF, Sherr EB (eds) Handbook of methods in aquatic microbial ecology. CRC Press, Boca Raton, FL, p 207-212

> Sherr EB, Sherr BF (1994) Bacterivory and herbivory: key roles of phagotrophic protists in pelagic food webs. Microb Ecol 28:223-235

- Sherr EB, Sherr BF (2002) Significance of predation by protists in aquatic microbial food webs. Antonie van Leeuwenhoek 81:293-308

Sherr EB, Sherr BF (2007) Heterotrophic dinoflagellates: a significant component of microzooplankton biomass and 
major grazers of diatoms in the sea. Mar Ecol Prog Ser 352:187-197

Sherr EB, Sherr BF, Wheeler PA (2005) Distribution of coccoid cyanobacteria and small eukaryotic phytoplankton in the upwelling ecosystem off the Oregon coast during 2001 and 2002. Deep-Sea Res II 52:317-330

Sherr EB, Sherr BF, Longnecker K (2006) Distribution of bacterial abundance and cell-specific nucleic acid content in the Northeast Pacific Ocean. Deep-Sea Res I 53: 713-725

Steemann-Nielsen E (1952) The use of radio-active carbon $\left({ }^{14} \mathrm{C}\right)$ for measuring organic production in the sea. J Cons Int Explor Mer 18:117-140

Stelfox-Widdicombe CE, Archer SD, Burkill PH, Stefels J (2004) Microzooplankton grazing in Phaeocystis and diatom-dominated waters in the southern North Sea in spring. J Sea Res 51:37-51

Strom SL, Brainard MA, Holmes JL, Olson MB (2001) Phytoplankton blooms are strongly impacted by microzooplankton grazing in coastal North Pacific waters. Mar Biol 138:355-368

Strom SL, Macri EL, Olson MB (2007) Microzooplankton grazing in the coastal Gulf of Alaska: variations in topdown control of phytoplankton. Limnol Oceanogr 52: 1480-1494

Stukel MR, Landry MR, Selph KE (2011) Nanoplankton mixotrophy in the eastern equatorial Pacific. Deep-Sea Res II 58:378-386

Taylor AG, Landry MR, Selph KE, Yang EJ (2011) Biomass, size structure and depth distributions of the microbial community in the eastern equatorial Pacific. Deep-Sea Res II 58:342-357

Teixeira IG, Figueiras FG (2009) Feeding behaviour and non-linear responses in dilution experiments in a coastal upwelling system. Aquat Microb Ecol 55:53-63

Teixeira IG, Figueiras FG, Crespo BG, Piedracoba S (2011) Microzooplankton feeding impact in a coastal upwelling

Editorial responsibility: Antonio Bode,

A Coruña, Spain system on the NW Iberian margin: the Ría de Vigo. Estuar Coast Shelf Sci 91:110-120

Thomsen H, Buck KR (1998) Nanoflagellates of central California waters: taxonomy, biogeography and abundance of primitive, green flagellates (Pedinophyceae, Prasinophyceae). Deep-Sea Res II 45:1687-1707

> Van Heukelem L, Thomas CS (2001) Computer-assisted high performance liquid chromatography method development with application to the isolation and analysis of phytoplankton pigments. J Chromatogr A 910:31-49

Vargas CA, Martínez RA, Cuevas LA, Pavez MA and others (2007) The relative importance of microbial and classical food webs in a highly productive coastal upwelling area. Limnol Oceanogr 52:1495-1510

Verity PG, Langdon C (1984) Relationship between lorica volume, carbon, nitrogen, and ATP content of tintinnids in Narragansett Bay. J Plankton Res 6:859-868

Walsh JJ, Row GT, Iverson RL, McRoy CP (1981) Biological export of shelf carbon is a sink of the global $\mathrm{CO}_{2}$ cycle. Nature 291:196-201

Worden AZ (2006) Picoeukaryote diversity in coastal waters of the Pacific Ocean. Aquat Microb Ecol 43:165-175

Worden AZ, Nolan JK, Palenik B (2004) Assessing the dynamics and ecology of marine picophytoplankton: the importance of the eukaryotic component. Limnol Oceanogr 49:168-179

Wright SW, Jeffrey SW (2006) Pigment markers for phytoplankton production. In: Volkman JK (ed) Marine organic matter: biomarkers, isotopes and DNA. The handbook of environmental chemistry, Vol 2N. SpringerVerlag, Berlin, p 71-104

Wright S, Mantoura RFC (1997) Guidelines for collection and pigment analysis of marine samples. In: Jeffrey SW, Mantoura RFC, Wright S (eds) Phytoplankton pigments in oceanography: buidelines to modern methods. UNESCO, Paris, p 429-445

Submitted: November 24, 2011; Accepted: April 24, 2012 Proofs received from author(s): July 17, 2012 